Research Article

\title{
Sonochemical Synthesis and Properties of $\mathbf{Y V O}_{4}: \mathbf{E u}^{3+}$ Nanocrystals for Luminescent Security Ink Applications
}

\author{
Chinh Dung Trinh $\mathbb{D}^{1,2}$ Phuong Thi Pham Hau, ${ }^{1}$ Thi My Dung Dang, \\ and Chien Mau Dang $\mathbb{D}^{1}$ \\ ${ }^{1}$ Institute for Nanotechnology, Vietnam National University, Ho Chi Minh City, Vietnam \\ ${ }^{2}$ The University of Science, Vietnam National University, Ho Chi Minh City, Vietnam \\ Correspondence should be addressed to Chien Mau Dang; dmchien@vnuhcm.edu.vn
}

Received 30 January 2019; Revised 1 April 2019; Accepted 18 April 2019; Published 10 July 2019

Guest Editor: Van Duong Dao

Copyright (c) 2019 Chinh Dung Trinh et al. This is an open access article distributed under the Creative Commons Attribution License, which permits unrestricted use, distribution, and reproduction in any medium, provided the original work is properly cited.

\begin{abstract}
Solutions and redispersible powders of nanocrystalline, europium-doped $\mathrm{YVO}_{4}$, are prepared via a wet chemical method using the ultrasonic processor (sonochemical) and microwave and thermal stirring. From X-ray diffraction (XRD) results, $\mathrm{YVO}_{4}: \mathrm{Eu}^{3+}$ nanoparticles synthesized using sonochemical method have better crystallinity than those prepared using thermal stirring and microwave methods exhibiting the tetragonal structure known for bulk material. From field-emission scanning electron microscopy (FE-SEM) and transmission electron microscopy (TEM) results, it is found that the size of nanoparticles is around $25 \mathrm{~nm}$ and increasing after annealing at $900^{\circ} \mathrm{C}$. From UV-Vis result, there is a peak at $270 \mathrm{~nm}$ corresponding to the absorption of $\mathrm{VO}_{4}{ }^{3-}$ groups. The photoluminescence (PL) results clearly show the strongest red emission peak at the wavelength around $618 \mathrm{~nm}$. The highest luminescent intensity is obtained for the sample prepared by the sonochemical method at $\mathrm{pH}=12$ and annealing temperature at $900^{\circ} \mathrm{C}$ for $4 \mathrm{~h}$. The average lifetimes of the $\mathrm{Eu}^{3+}$ ions in the samples annealed at 300,600 , and $900^{\circ} \mathrm{C}$ for $1 \mathrm{~h}$ at $618 \mathrm{~nm}$ emission under $275 \mathrm{~nm}$ excitation are $0.36,0.62$, and $0.64 \mathrm{~ms}$, whereas sample annealed at $900^{\circ} \mathrm{C}$ for $4 \mathrm{~h}$ has lifetime of $0.70 \mathrm{~ms}$. The security ink, containing synthesized $\mathrm{YVO}_{4}: \mathrm{Eu}^{3+}$ nanoparticles, is dispersed in glycerol and other necessary solvents. The experimental security labels are printed by inkjet using the electrohydrodynamic printing technique. The resulting lines represented to the security labels are analyzed by the 3D microscope equipment and UV $20 \mathrm{~W}$ mercury lamp with a wavelength of $\sim 254 \mathrm{~nm}$. The seamless line of the printed security label has the value of the width at $\sim 230 \mu \mathrm{m}$, thickness at $\sim 0.68 \mu \mathrm{m}$, and distance between two adjacent lines at $800 \mu \mathrm{m}$. This result is compatible for producing security labels in small size (millimeter) in order to increase security property.
\end{abstract}

\section{Introduction}

The study of rare earth doped luminescence materials has been largely motivated by the prospect of original specific applications such as electroluminescent techniques, biological labels, and integrated optics [1-6].

Moreover, rare earth nanoparticles are interesting due to their marked improvement in lumen output, color rendering index, energy efficiency, and greater radiation stability [6-11].

$\mathrm{YVO}_{4}: \mathrm{Eu}^{3+}$ has large application in color television cathode ray tube displays [12] and high-pressure mercury lamps [13] as a red phosphor. The photoluminescence quantum yield of the europium emission is as high as $70 \%$ in $\mathrm{YVO}_{4}$ with the excitation by UV light [14]. It is also applied in biology [15-17] and specially in producing security ink. The vanadate group $\left(\mathrm{V}^{5+}-\mathrm{O}^{2-}\right.$ charge transfer band) in $\mathrm{YVO}_{4}: \mathrm{Eu}^{3+}$ phosphor is excited by ultraviolet radiation, and this provides efficient energy transfer to $\mathrm{Eu}^{3+}[18]$.

$\mathrm{YVO}_{4}: \mathrm{Eu}^{3+}$ phosphor can be prepared by different methods, for example, high-temperature solid state method [19], combination method [20], microwave rapid heating method [21-23], sol-gel method [24], and hydrothermal reaction method [25]. Recent studies have shown that there 
is a tremendous potential in nanoscale rare earth doped luminescence materials in abovementioned fields.

In recent years, the inkjet technique has been in research to make spare parts such as electric circuits and biosensor [26-35]. The advantage of this technique is having fewer steps in preparation and ability to print in many different bases such as conductive base, unconductive base, solid base, and flexible base. This inkjet technique requires research in the printing process and inkjet ink. In 2012, Meruga et al. investigated security ink from the rare earth nanoparticles $\beta$ $\mathrm{NaYF}_{4}$-doped $\mathrm{Yb}^{3+} / \mathrm{Er}^{3+}$ and $\mathrm{Yb}^{3+} / \mathrm{Tm}^{3+}$ to print security QR code on paper and PET by Optomec direct-write aerosol jetting [36]. According to the work of Gupta et al. in 2010, they evaluated the security ink made of rare earth nanoparticle $\mathrm{Y}_{2} \mathrm{O}_{3}$ doped $\mathrm{Eu}^{3+}\left(\mathrm{Y}_{2} \mathrm{O}_{3}: \mathrm{Eu}^{3+}\right)$, and the samples in this research were printed by screen printing techniques [37]. The purpose of our security inkjet technique is making products with high security. With inkjet technology and this security ink, we study printing the labels with the demand of high security on money, visa, certificate, and military products. The high security characteristic of the product is determined by two factors-the first is small size and delicacy of the printed label (related to the printing technique) and second is the strong emissivity of printed label under UV (related to optical emission of $\mathrm{YVO}_{4}: \mathrm{Eu}^{3+}$ nanoparticles in the ink). The emissivity of $\mathrm{YVO}_{4}: \mathrm{Eu}^{3+}$ nanoparticles is affected by many factors such as particle size and crystallinity, doping level of $\mathrm{Eu}^{3+}$ ions into $\mathrm{YVO}_{4}$, etc. All these parameters are affected by the production method applied for nanoparticles [38-42].

In this study, we use the wet chemical method to synthesize $\mathrm{YVO}_{4}: \mathrm{Eu}^{3+}$. Our purpose is to apply $\mathrm{YVO}_{4}: \mathrm{Eu}^{3+}$ as phosphor in security ink. Hence, performing research in producing the $\mathrm{YVO}_{4}: \mathrm{Eu}^{3+}$ nanoparticles with strong luminescent intensity is crucial along with the research in inkjet process. Regarding the references on synthesis of $\mathrm{YVO}_{4}: \mathrm{Eu}^{3+}$ nanoparticles by wet-chemical method $[12-21,38-42]$, we use three different routes to synthesize $\mathrm{YVO}_{4}: \mathrm{Eu}^{3+}$ nanoparticles, which are thermal stirring, microwave methods, and ultrasonic methods, in order to compare the luminescent level of the nanoparticles. According to the published results, the best doping level of $\mathrm{Eu}^{3+}$ in $\mathrm{YVO}_{4}$ for luminescence properties is $5 \mathrm{~mol} \%$ $[38,43-55]$. We use $\mathrm{YVO}_{4}: \mathrm{Eu}^{3+}$ nanoparticles to produce ink for PS JET $300 \mathrm{~V}$ inkjet printer. This printer is operated by the electrohydrodynamic (EHD) inkjet technique. The advantage of EHD inkjet technique is the ability to print labels in small size (in micrometers) on various material substrates.

\section{Materials and Methods}

2.1. Materials. $\mathrm{Y}\left(\mathrm{NO}_{3}\right)_{3} \cdot 6 \mathrm{H}_{2} \mathrm{O} \quad(99.8 \%, \quad$ Aldrich), $\mathrm{Eu}\left(\mathrm{NO}_{3}\right)_{3} \cdot 5 \mathrm{H}_{2} \mathrm{O}$ (99.9\%, Aldrich), and $\mathrm{Na}_{3} \mathrm{VO}_{4}$ (99.98\%, Aldrich) are used as starting materials. $\mathrm{NaOH}$ (99\%, Merck) is used to control $\mathrm{pH}$.

$\mathrm{C}_{3} \mathrm{H}_{8} \mathrm{O}_{3}$ (99.5\%, Merck), $\mathrm{C}_{2} \mathrm{H}_{6} \mathrm{O}$ (99.5\%), $\mathrm{C}_{4} \mathrm{H}_{8} \mathrm{O}_{2}$ (99.8\%, Merck), and $\mathrm{C}_{2} \mathrm{H}_{6} \mathrm{O}_{2}$ (99.5\%, Merck) are solvents and binding agents used in the synthesis of security ink.
2.2. Synthesis of $\mathrm{YVO}_{4}: \mathrm{Eu}^{3+}$ Nanoparticles and Security Ink. $\mathrm{YVO}_{4}: \mathrm{Eu}^{3+}$ nanoparticles are synthesized by the wet chemical method. Dissolving $0.88 \mathrm{~g}$ of $\mathrm{Y}\left(\mathrm{NO}_{3}\right)_{3} \cdot 6 \mathrm{H}_{2} \mathrm{O}$ $(2.3 \mathrm{mmol})$ and $0.05 \mathrm{~g}$ of $\mathrm{Eu}\left(\mathrm{NO}_{3}\right)_{3} \cdot 5 \mathrm{H}_{2} \mathrm{O}(0.12 \mathrm{mmol})$ into $15 \mathrm{ml} \mathrm{DI}$ water $\left(\mathrm{Eu}^{3+}\right.$ doping molar concentration is $5 \%$ ) in 15 min leads to the formation of solution $\mathrm{A}$, whereas $0.44 \mathrm{~g}$ of $\mathrm{Na}_{3} \mathrm{VO}_{4}(2.4 \mathrm{mmol})$ in $15 \mathrm{ml}$ DI water is solution $\mathrm{B}$. Mixing solution A with solution B dropwise leads to white precipitation in the mixture. The $\mathrm{pH}$ value of mixture is adjusted to 12 by using $5 \mathrm{M}$ of $\mathrm{NaOH}$.

This mixture is heat-treated by three different ways for comparison, which are thermal stirring at $\sim 150^{\circ} \mathrm{C}$ in $1 \mathrm{~h}$, microwave in $15 \mathrm{~min}$ by Mars 6 (CEM Corporation) [21-23], and sonochemical by ultrasonic liquid processors VCX 750 (Sonics and Materials) with electrical frequency $20 \mathrm{kHz}$ in $15 \mathrm{~min}$. Synthesized $\mathrm{YVO}_{4}: \mathrm{Eu}^{3+}$ nanoparticles are dried at $60^{\circ} \mathrm{C}$ and annealed at 300,600 , and $900^{\circ} \mathrm{C}$ in an oven (Carbolite Gero, Max. temp. up to $1100^{\circ} \mathrm{C}$ ) for $1 \mathrm{~h}$. The formation of $\mathrm{YVO}_{4}: \mathrm{Eu}^{3+}$ nanoparticles follows equation (1):

$$
\mathrm{Y}^{3+}+\mathrm{Eu}^{3+}+\mathrm{VO}_{4}{ }^{3-} \longrightarrow \mathrm{YVO}_{4}: \mathrm{Eu}^{3+}
$$

The security ink using $\mathrm{YVO}_{4}: \mathrm{Eu}^{3+}$ nanoparticles is synthesized by mixing $\mathrm{YVO}_{4}: \mathrm{Eu}^{3+}$ nanoparticles in such solvents as glycerin, ethanol, ethyl acetate, and ethylene glycol at appropriate ratios.

2.3. Security Printing. The test patterns are printed onto glass substrate by a commercial printer (PS JET $300 \mathrm{~V}$ ). This printer is operated by the electrohydrodynamic (EHD) inkjet technique.

2.4. Characterization. The prepared $\mathrm{YVO}_{4}: \mathrm{Eu}^{3+}$ nanoparticle samples are studied by UV-Vis absorption spectroscopy by using a double-beam spectrophotometer in the wavelength range from 200 to $900 \mathrm{~nm}$. Particle size is determined by transmission electron microscopy (TEM) and field emission scanning electron microscopy (FESEM). Samples for TEM measurements are suspended in ethanol and ultrasonically dispersed. The suspension drops are placed on a copper grid coated with carbon. The crystallite structure of $\mathrm{YVO}_{4}: \mathrm{Eu}^{3+}$ is analyzed by X-ray diffraction spectroscopy. The emission spectra are recorded at room temperature using a Hitachi F-4500 spectrophotometer. The decay of luminescence is measured by a Horiba Deltaflex ${ }^{\mathrm{TM}}$ with $275 \mathrm{~nm}$ SpectraLED excitation source.

The security ink viscosity is analyzed by an $\mathrm{m}-\mathrm{VROC}^{\mathrm{TM}}$ VISCOMETER. The samples after printed by inkjet printer are synthesized by a 3D microscope (Sensofar Metrology) and UV $20 \mathrm{~W}$ mercury lamps (Germicidal lamp, Sankyo Denki Co.) having a wavelength of around $254 \mathrm{~nm}$.

\section{Results and Discussion}

3.1. Effect of Different Synthesis Methods on the Formation of $\mathrm{YVO}_{4}: \mathrm{Eu}^{3+}$ Nanoparticles. The wet chemical method is applied in all experiments; however, there is difference in the 
heating method during synthesis process as mentioned above. Three synthesized samples correspond to three different methods with the same chemical components and ratios. The doping concentration of $\mathrm{Eu}^{3+}$ is $5 \mathrm{~mol} \%$ in $\mathrm{YVO}_{4}$ host $\left(\mathrm{Y}_{0.95} \mathrm{Eu}_{0.05} \mathrm{VO}_{4}\right)$, which had been optimized previously by Georgescu et al. [43], Kumar et al. [44], and He et al. [45]. Each heating method has different effect to $\mathrm{YVO}_{4}$ particles crystallinity and doped ability of ion $\mathrm{Eu}^{3+}$ to host matrix. The crystallization and doped ability have crucial effect to luminescent intensity of $\mathrm{YVO}_{4}: \mathrm{Eu}^{3+}$ nanoparticles. The XRD patterns recorded for the $\mathrm{YVO}_{4}: \mathrm{Eu}^{3+}$ samples are shown in Figure 1. All diffraction peaks were successfully attributed to known tetragonal phase of $\mathrm{YVO}_{4}$ (JCPDS, No. 17-0341) $[41,42,46]$.

Among three preparation methods, the highest peak intensity is observed for the sample fabricated by the sonochemical treatment, that reveals the best crystallinity level of $\mathrm{YVO}_{4}: \mathrm{Eu}^{3+}$ nanoparticles in this sample. According to theory and references of sound waves, the constitution of ultrasound region happens with sound wave frequency above $20 \mathrm{kHz}$. The ultrasound region can be divided into two parts: one where the cavitation phenomenon takes place $(20-100 \mathrm{kHz})$, called power ultrasound, and the other where no cavitation occurs $(5-10 \mathrm{MHz})$, used for diagnostics. Sonochemical effects depend on the cavitation phenomenon. According to the "hot spot" theory, each cavitation bubble behaves like a microreactor, which, in aqueous systems, at an ultrasonic frequency of $20 \mathrm{kHz}$ each cavitation bubble collapse acts as a localized "hotspot" generating temperatures of about $4000 \mathrm{~K}$ and pressures in excess of 1000 atmospheres [47-51].

A series of radicals, such as $\mathrm{H}^{*}$ and $\mathrm{OH}^{*}$, are formed, by the irradiation process of ultrasound to water, at the gasphase interface of the cavitation bubbles, and the responsibility for the enhanced reactivity to a lesser extent, in the bulk solution [51].

These factors have positive effect to the crystalline nanoparticle formation and incorporation of $\mathrm{Eu}^{3+}$ ions into $\mathrm{YVO}_{4}$ lattice. These factors have effect to the luminescent intensity of $\mathrm{YVO}_{4}: \mathrm{Eu}^{3+}$ nanoparticles.

The TEM micrographs and size distribution diagrams of $\mathrm{YVO}_{4}: \mathrm{Eu}^{3+}$ nanoparticles prepared by sonochemical and thermal stirring methods are shown in Figure 2. The monodispersion state of $\mathrm{YVO}_{4}: \mathrm{Eu}^{3+}$ nanoparticles is evident. In Figure 2(a), more even size distribution is observed with maximum at $\sim 25 \mathrm{~nm}$. The wider and nonhomogeneous size distribution is seen in Figure 2(b). The TEM results agreed with the XRD results shown in Figure 1.

There are three major steps in the excitation-emission process of YVO4: $\mathrm{Eu}^{3+}$ under UV radiation. Firstly, UV radiation is absorbed by $\mathrm{VO}_{4}{ }^{3-}$ groups. However, UV radiation can be directly absorbed by $\mathrm{Eu}^{3+}$ ions, and this is dependent on the wavelength. Secondly, the migration of activation energy through vanadate sublattice leads to the transferring of the excited energy to $\mathrm{Eu}^{3+}$ ions, and the last step is the production of strong red emission by the deexcitation process of excited $\mathrm{Eu}^{3+}$ ions $[15,41,52,56]$. A proposed energy transfer mechanism demonstrating the above process is shown in Figure 3.

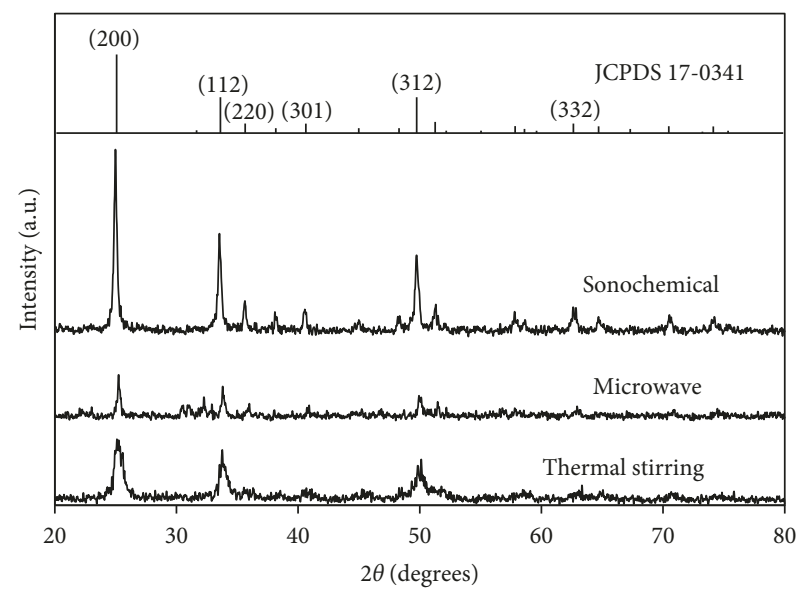

FIGURE 1: The XRD pattern of $\mathrm{YVO}_{4}: \mathrm{Eu}^{3+}$ nanoparticles synthesized with a different method.

In Figure 4 (left inset), the UV-V is spectra of $\mathrm{YVO}_{4}$ : $\mathrm{Eu}^{3+}$ nanoparticles prepared by sonochemical and wavelength and thermal stirring methods are shown. The redispersed dry powder of $\mathrm{YVO}_{4}: \mathrm{Eu}^{3+}$ in the same amount of deionized water was stirred $2-3 \mathrm{~min}$, resulting in the transparent colloid representing the absorption spectrum. There is a peak at around $270 \mathrm{~nm}$ in these three samples that proved the existence of absorption in the $\mathrm{VO}_{4}{ }^{3-}$ groups $[39,41,52,56]$. According to references, it is explained as the attribution to the charge transfer from oxygen ligands to the central vanadium atom in $\mathrm{VO}_{4}{ }^{3-}$ group $[15,40,41]$. The UV-Vis spectra in Figure 4 (left inset) are crucial regarding to the luminescence mechanism of $\mathrm{YVO}_{4}: \mathrm{Eu}^{3+}$ nanoparticles, and it proves that there is an energy absorption and transfer from $\mathrm{VO}_{4}{ }^{3-}$ to $\mathrm{Eu}^{3+}$. The sample of the sonochemical method exhibits the strongest absorption while the one of the thermal stirring methods exhibits the weakest absorption.

In Figure 4, the photoluminescence emission spectra of $\mathrm{YVO}_{4}: \mathrm{Eu}^{3+}$ nanoparticles prepared by three synthesis methods are shown. The samples were excited at $\sim 275 \mathrm{~nm}$. The sharp lines in the range from 550 to $750 \mathrm{~nm}$ correspond to the transitions from the excited ${ }^{5} \mathrm{D}_{0} \longrightarrow{ }^{7} \mathrm{~F}_{\mathrm{J}}$ of $\mathrm{Eu}^{3+}$ ions (Figure 3) [15, 41, 57-59]. There is no obvious vanadate group emission band indicating the transfer of absorption energy of the vanadate groups to $\mathrm{Eu}^{3+}$ ions. There is assignation of strongest red emission peak at $618 \mathrm{~nm}$ to the ${ }^{5} \mathrm{D}_{0} \longrightarrow{ }^{7} \mathrm{~F}_{2}$ transition, emission peak at $590 \mathrm{~nm}$ to ${ }^{5} \mathrm{D}_{0} \longrightarrow{ }^{7} \mathrm{~F}_{1}$ of $\mathrm{Eu}^{3+}$ ions, and strong emission peak at $692 \mathrm{~nm}$ to the ${ }^{5} \mathrm{D}_{0} \longrightarrow{ }^{7} \mathrm{~F}_{4}$ transition $[15,40,41] . \mathrm{Eu}^{3+}$ ions occupy asymmetry inversion center instead of $\mathrm{Y}^{3+}$ in the strongest emission from ${ }^{5} \mathrm{D}_{0} \longrightarrow{ }^{7} \mathrm{~F}_{2}$ transition $[15,41]$. The sample produced by the sonochemical method has the strongest intensity at $618 \mathrm{~nm}$, as compared to that of other samples. Regarding this result, the characteristics of the ultrasonic processor, high local temperature and pressure, are attributed to the forming of $\mathrm{YVO}_{4}: \mathrm{Eu}^{3+}$ nanoparticles with high crystalline structure and better doping of $\mathrm{Eu}^{3+}$ ions to $\mathrm{YVO}_{4}$ lattice. We also assumed that sound waves with characteristic of mechanical waves affect the doping of $\mathrm{Eu}^{3+}$ 

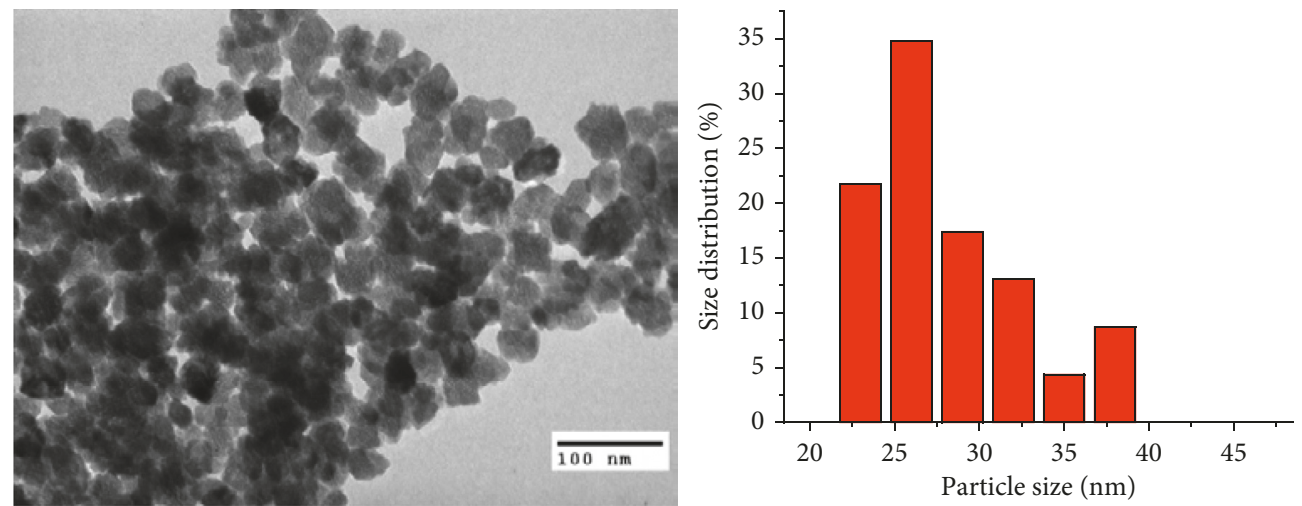

(a)
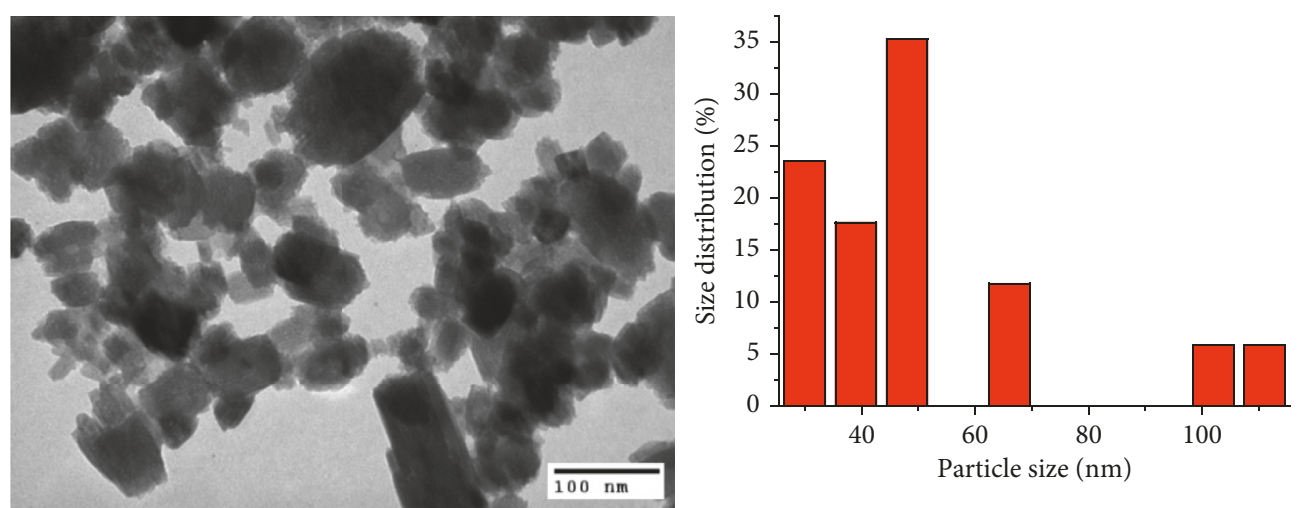

(b)

FIGURE 2: TEM micrographs and the size distribution diagram of $\mathrm{YVO}_{4}: \mathrm{Eu}^{3+}$ nanoparticles synthesized by sonochemical (a) and thermal stirring (b).

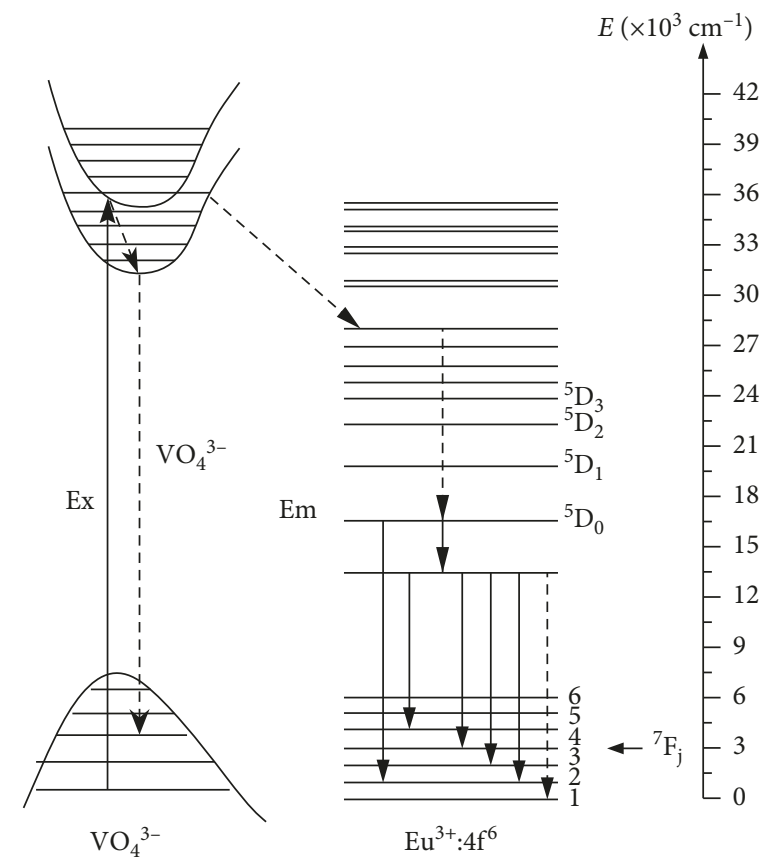

FIgURe 3: Energy levels and transitions scheme of $\mathrm{Eu}^{3+}$. Vertical arrows: absorption and emission transitions.

ions to the $\mathrm{YVO}_{4}$ lattice. And, it leads to the highest intensity of emission peak [51]. Figure 4 (right inset) is the image of $\mathrm{YVO}_{4}: \mathrm{Eu}^{3+}$ nanoparticles powder, synthesized by sonochemical method, under excitation at $254 \mathrm{~nm}$ by the UV lamp. The powder turns red under the UV lamp corresponding to dominant emission at $618 \mathrm{~nm}$. 


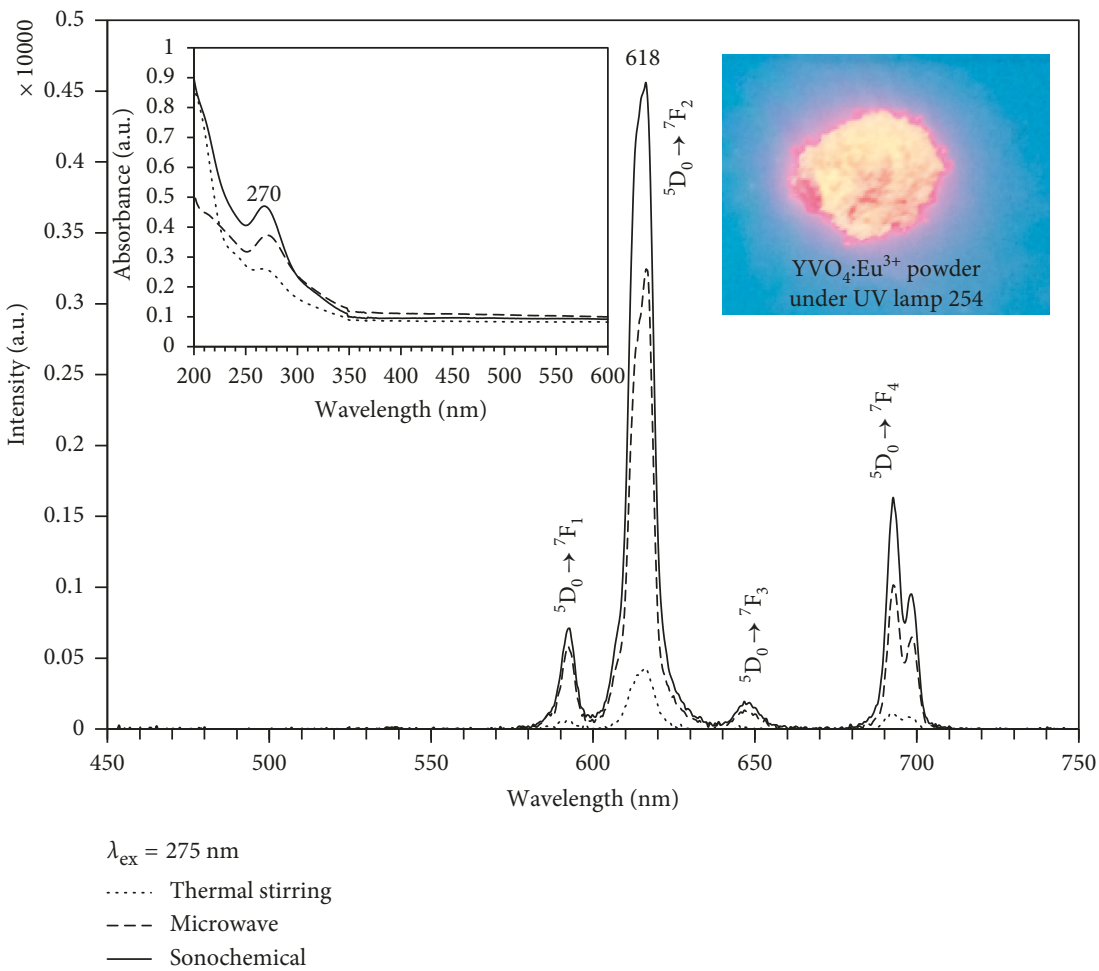

FIGURE 4: Photoluminescence spectra of $\mathrm{YVO}_{4}: \mathrm{Eu}^{3+}$ nanoparticles synthesized with a different method. Right inset shows UV-V is spectra of $\mathrm{YVO}_{4}: \mathrm{Eu}^{3+}$ nanoparticles synthesized with a different method. Left inset is image of $\mathrm{YVO}_{4}: \mathrm{Eu}^{3+}$ powder synthesized with sonochemical method under UV lamb $254 \mathrm{~nm}$.

The purpose is synthesizing $\mathrm{YVO}_{4}: \mathrm{Eu}^{3+}$ nanoparticles with strong luminescence. There are many factors which affect the light emitting of $\mathrm{YVO}_{4}: \mathrm{Eu}^{3+}$ nanoparticles (related to the light emitting mechanism) such as the doping level of $\mathrm{Eu}^{3+}$ ions, particle crystalline, and nanoparticle size. Among these factors, the nanoparticle crystallinity and the incorporation of $\mathrm{Eu}^{3+}$ ion into the $\mathrm{Y}^{3+}$ positions in the lattice of $\mathrm{YVO}_{4}: \mathrm{Eu}^{3+}$ nanoparticles play important roles in the increasing of luminescence. As to the above result, the $\mathrm{YVO}_{4}: \mathrm{Eu}^{3+}$ nanoparticles with highest luminescent intensity are synthesized by the sonochemical method, and so, this method will be used for the future research.

$\mathrm{YVO}_{4}: \mathrm{Eu}^{3+}$ nanoparticles are synthesized by the wet chemical method with De-ion water as solvent, in which the $\mathrm{pH}$ parameter affects the forming of particles as well as the crystalline growth of nanoparticles. Hence, the $\mathrm{pH}$ of aqueous vanadate solution is an important parameter in the synthesis $[22,23,43,60]$. The samples are synthesized with the $\mathrm{pH}$ value variation (adjusted by $5 \mathrm{M} \cdot \mathrm{NaOH}$ ) in the solution as follows: $8,10,12$, and 14 (with sonochemical method and the ratio of chemical as mentioned above). The change in the luminescence intensity of $\mathrm{YVO}_{4}: \mathrm{Eu}^{3+}$ nanoparticles is shown in Figure 5.

Figure 5 shows the main emission is at $618 \mathrm{~nm}$ due to ${ }^{5} \mathrm{D}_{0} \longrightarrow{ }^{7} \mathrm{~F}_{2}$ transition with the strongest emissivity. The samples are excited at $\sim 275 \mathrm{~nm}$. At $618 \mathrm{~nm}$, the luminescence intensity of sample with $\mathrm{pH}=12$ is strongest, the second is $\mathrm{pH}=14$, and the weakest is $\mathrm{pH}=8$. This can be explained that the reaction does not occur when $\mathrm{pH}>12$ and only the precipitation of very small particles of $\mathrm{Y}(\mathrm{OH})_{3}$ takes place instead of $\mathrm{YVO}_{4}$. When the $\mathrm{pH}$ is smaller than 12, the color of the solution changes slowly from light to dark yellow. This may be the attribution to the forming of polyvanadate species $[23,43]$. Hence, $\mathrm{pH}=12$ is optimal for emissivity of $\mathrm{YVO}_{4}: \mathrm{Eu}^{3+}$ nanoparticles.

\subsection{Effect of Annealing Temperature on the Characteristics of} $\mathrm{YVO}_{4}: \mathrm{Eu}^{3+}$ Nanoparticles Synthesized by Sonochemical Method. The annealing process is carried out after nanoparticles formation, and it plays an important role in increasing the crystallinity and decreasing structure distortion of rare earth nanocrystals $[38,40,45] . \mathrm{YVO}_{4}: \mathrm{Eu}^{3+}$ nanoparticles are synthesized by the sonochemical method and then centrifuged at $9000 \mathrm{rpm}$. The final powder is dried at $60^{\circ} \mathrm{C}$ in $6 \mathrm{~h}$ and then annealed at 300,600 , and $900^{\circ} \mathrm{C}$ in $1 \mathrm{~h}$.

Figure 6 shows the XRD patterns, as recorded for the $\mathrm{YVO}_{4}: \mathrm{Eu}^{3+}$ nanoparticles prepared at 300,600 , and $900^{\circ} \mathrm{C}$. Only the tetragonal phase of $\mathrm{YVO}_{4}$ (JCPDS, No. 17-0341) is observed in all samples. The sample annealed at $900^{\circ} \mathrm{C}$ for $1 \mathrm{~h}$ has better crystallinity in comparison to that of the samples annealed at 300 and $600^{\circ} \mathrm{C}$ for $1 \mathrm{~h}$. This result shows that annealing at $900^{\circ} \mathrm{C}$ is preferable for the sample synthesis.

Figure 7 shows the FE-SEM patterns of the samples annealed at 300,600 , and $900^{\circ} \mathrm{C}$ for $1 \mathrm{~h}$ and the energy dispersive X-ray (EDX) spectra of $\mathrm{YVO}_{4}: \mathrm{Eu}^{3+}$ nanoparticles annealed at $900^{\circ} \mathrm{C}$ for $1 \mathrm{~h}$. Using ImageJ software for calculation, the correlative average particle sizes are found to be 


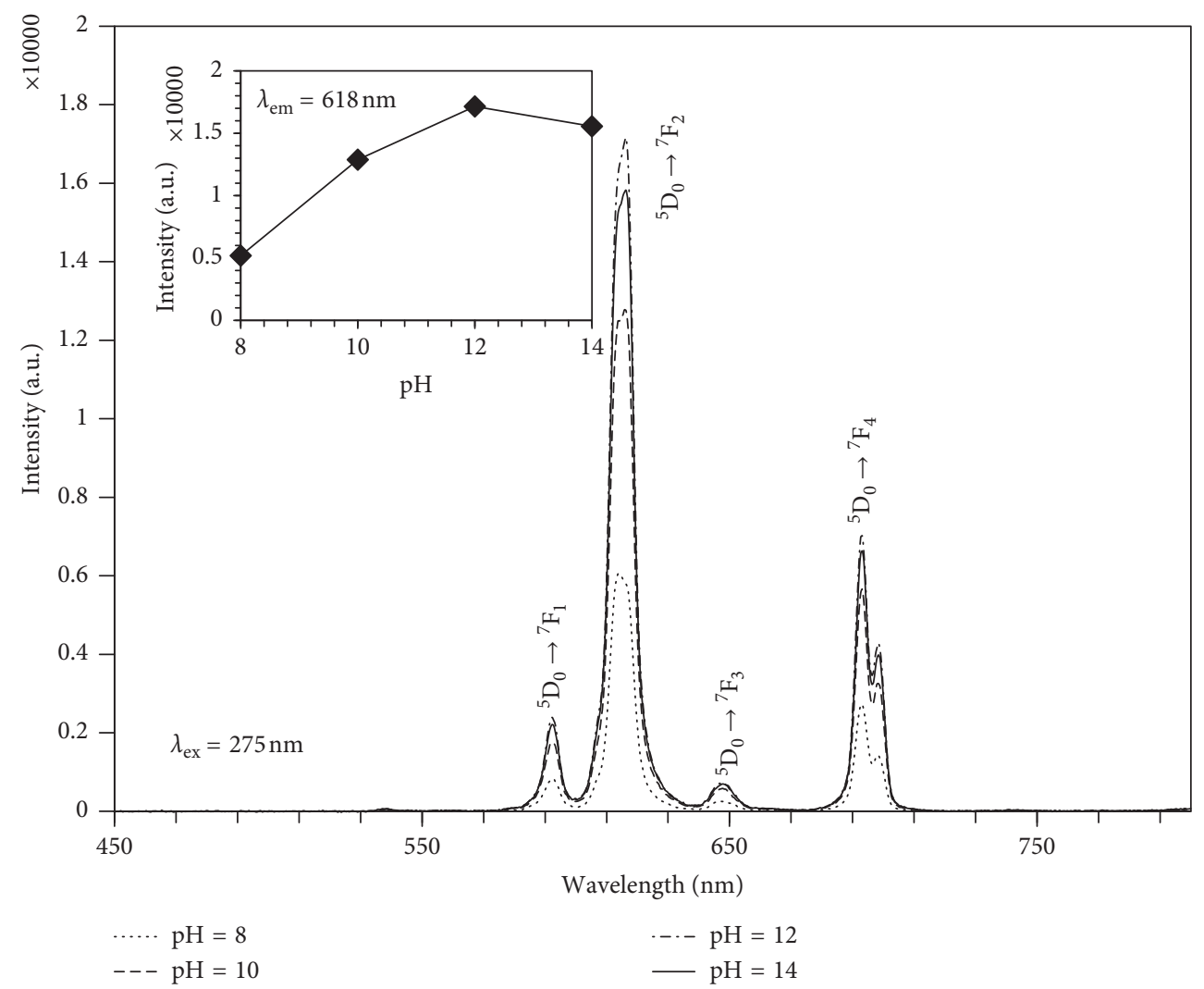

Figure 5: Photoluminescence spectra of samples with different $\mathrm{pH}$ values. Inset shows $\mathrm{pH}$ value dependence on ${ }^{5} \mathrm{D}_{0} \longrightarrow{ }^{7} \mathrm{~F}_{2}$ intensity.

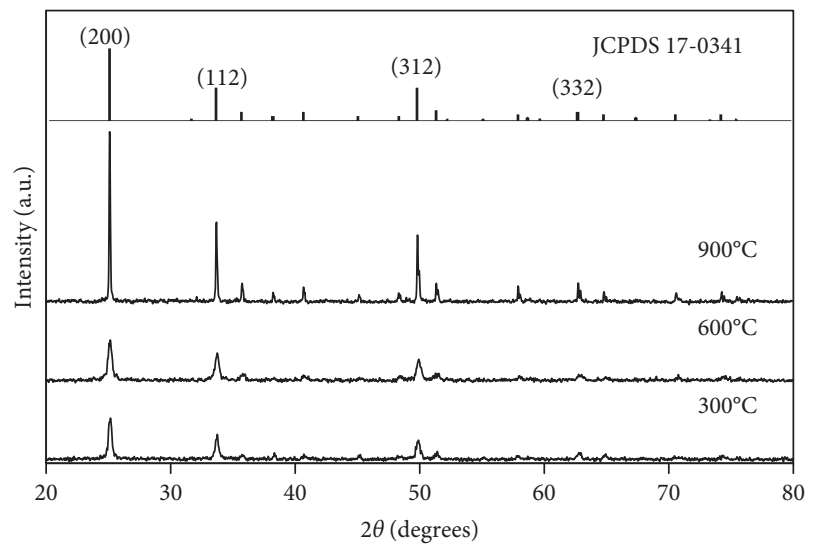

FIGURE 6: XRD samples of $\mathrm{YVO}_{4}: \mathrm{Eu}^{3+}$ nanoparticles synthesized at different annealing temperatures.

$47 \mathrm{~nm}, 78 \mathrm{~nm}$, and $170 \mathrm{~nm}$. Thus, when the annealing temperature increases, the particle size also increases. The increasing of $\mathrm{YVO}_{4}: \mathrm{Eu}^{3+}$ nanoparticles size along with increasing annealing temperature has been observed by Georgescu et al. [38] and Li et al. [61]. This phenomenon can be explained by the nephelauxetic effect which is related to the metal-ligand bond covalency. Therefore, the covalency of $\mathrm{Eu}^{3+}-\mathrm{O}^{2-}$ bonds in $\mathrm{YVO}_{4}: \mathrm{Eu}^{3+}$ increases as the temperature increases in thermal treatment. There is a relation between the increase of covalency with nanoparticle size and the expansion of the cell parameters of $\mathrm{YVO}_{4}: \mathrm{Eu}^{3+}$ nanoparticles in rapport with the bulk material.
The EDX spectrum in samples of $\mathrm{YVO}_{4}: \mathrm{Eu}^{+}$nanoparticles affirms the existence of yttrium $(\mathrm{Y})$, oxygen $(\mathrm{O})$, vanadium $(\mathrm{V})$, and europium $(\mathrm{Eu})$ factors, indicating that $\mathrm{Eu}^{3+}$ ions are doped into the $\mathrm{YVO}_{4}$ nanocrystals.

The photoluminescence spectra which appeared under excitation at $275 \mathrm{~nm}$ of samples fabricated at different annealing temperatures are shown in Figure 8. Right inset is the UV-V is spectra of $\mathrm{YVO}_{4}: \mathrm{Eu}^{3+}$ nanoparticles with different annealing temperatures-left inset is the diagram presenting the dependence of ${ }^{5} \mathrm{D}_{0} \longrightarrow{ }^{7} \mathrm{~F}_{2}$ intensity on annealing temperature. The optical emission mechanism is the absorption of ultraviolet light by $\mathrm{VO}_{4}{ }^{3-}$ groups and transfer of energy to $\mathrm{Eu}^{3+}$, the energy which is released in the form of fluorescence [61-63]. Hence, the absorption of $\mathrm{VO}_{4}{ }^{3-}$ is displayed in Figure 8 (right inset). There is an absorption in the $\mathrm{VO}_{4}{ }^{3-}$ groups related to the peaks at $270 \mathrm{~nm}$ of three samples. In accordance with references, we can explain that the oxygen ligands attributed to the charge transfer to central vanadium atom in $\mathrm{VO}_{4}{ }^{3-}$ group. The result of UV-Vis spectra is important because of the luminescent characteristic of $\mathrm{YVO}_{4}: \mathrm{Eu}^{3+}$ nanoparticles resulting in the energy absorption and transfer from $\mathrm{VO}_{4}{ }^{3-}$ to $\mathrm{Eu}^{3+}[22,41]$. All three samples have the strongest peak at $618 \mathrm{~nm}$ resulting from ${ }^{5} \mathrm{D}_{0} \longrightarrow{ }^{7} \mathrm{~F}_{2}$ transition. This leads to the indication of the occupying of $\mathrm{Eu}^{3+}$ ions to the asymmetry inversion center instead of $\mathrm{Y}^{3+}$. Figure 8 (left inset) shows the dependence of luminescence intensity on annealing temperature. With the annealing at $900^{\circ} \mathrm{C}$ for $1 \mathrm{~h}, \mathrm{YVO}_{4}: \mathrm{Eu}^{3+}$ nanoparticles have the strongest luminescence intensity, which can be explained that the increase of temperature will 


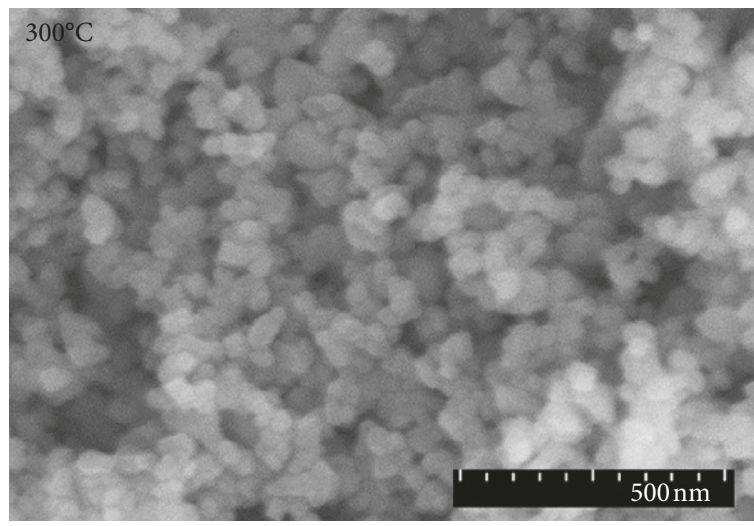

(a)

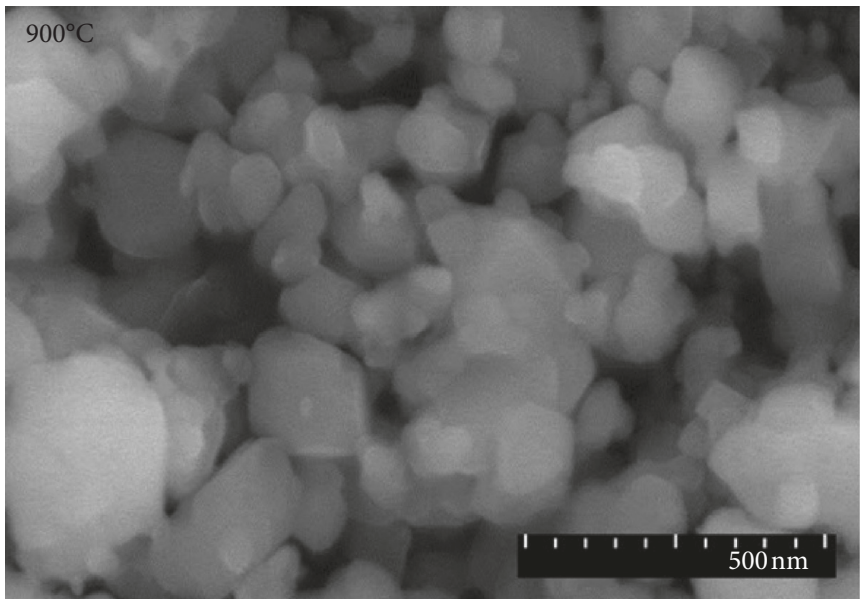

(c)

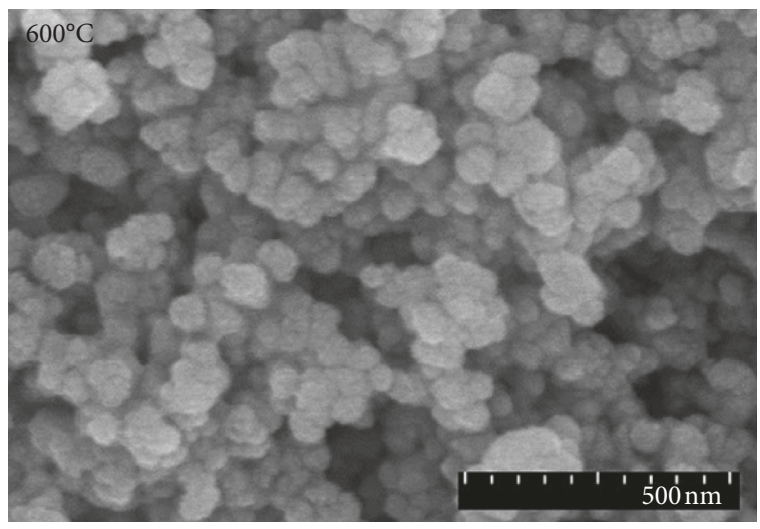

(b)

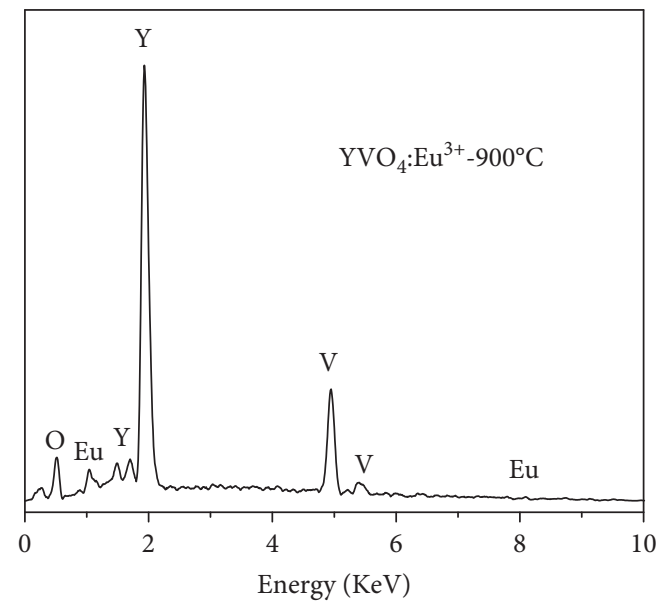

(d)

FIGURE 7: FE-SEM micrographs of $\mathrm{YVO}_{4}: \mathrm{Eu}^{3+}$ nanoparticles at different annealing temperatures and corresponding EDX spectrum of samples annealed at $900^{\circ} \mathrm{C}$ (in $1 \mathrm{~h}$ ).

decrease the number of top surface defects. However, the annealing temperature in this research remains not over $900^{\circ} \mathrm{C}$ in order to control the size of nanoparticles. Due to the nanoparticle size increasing, the disadvantage appeared in the preparation of security ink.

Figure 9 shows the photoluminescence spectra of samples annealed at $900^{\circ} \mathrm{C}$ for 2,4 , and $5 \mathrm{~h}$ with excitation at $\sim 275 \mathrm{~nm}$. The more increasing of $\mathrm{Eu}^{3+}$ local symmetry environment causes the increase of the strongest emission from ${ }^{5} \mathrm{D}_{0} \longrightarrow{ }^{7} \mathrm{~F}_{2}$ transition over annealing time from $2 \mathrm{~h}$ to $4 \mathrm{~h}$. However, the annealing time of $5 \mathrm{~h}$ leads to the lower intensity than that at $4 \mathrm{~h}$. The relative intensity ratio of ${ }^{5} \mathrm{D}_{0} \longrightarrow{ }^{7} \mathrm{~F}_{2}$ to ${ }^{5} \mathrm{D}_{0} \longrightarrow{ }^{7} \mathrm{~F}_{1}$ peaks can show the symmetry rate of local environment of $\mathrm{Eu}^{3+}$ ions [23, 61, 64]. To reveal the influence of heat treating temperature and time on the luminescence properties, the relative intensity ratios of ${ }^{5} \mathrm{D}_{0} \longrightarrow{ }^{7} \mathrm{~F}_{2}$ and ${ }^{5} \mathrm{D}_{0} \longrightarrow{ }^{7} \mathrm{~F}_{1}$ transitions in the samples are calculated, and the results are shown in Table 1.

In three samples annealed at 300,600 , and $900^{\circ} \mathrm{C}$ for $1 \mathrm{~h}$, a tendency to decrease the intensity ratio with increasing heat treating temperature indicates the increase of symmetry of local environment of $\mathrm{Eu}^{3+}$ ions heat treatment temperature. The highest relative intensity ratio was obtained in the sample annealed at $300^{\circ} \mathrm{C}$ and the lowest in the sample at $900^{\circ} \mathrm{C}$, which shows that highest $\mathrm{Eu}^{3+}$ local symmetry environment is in the sample treated at $900^{\circ} \mathrm{C}$. These results can be explained that the low annealing temperature (at $300^{\circ} \mathrm{C}$ ) leads to the slower crystal growth rate, the sample obtains enough energy due to increase in the annealing temperature (at $900^{\circ} \mathrm{C}$ ) and has better crystallinity.

In four samples annealed at $900^{\circ} \mathrm{C}$ for $2,3,4$, and $5 \mathrm{~h}$, the relative intensity ratio decreases gradually from $2 \mathrm{~h}$ to $4 \mathrm{~h}$ sample, but this ratio in $5 \mathrm{~h}$ sample is higher than $4 \mathrm{~h}$ sample. It shows that the local symmetry of $\mathrm{Eu}^{3+}$ environment is the highest in the $4 \mathrm{~h}$ sample in comparison with other samples. The reason is that the particles have enough time and energy to have better crystallite growth [38, 40,65]. However, increasing of the heat-treating time to $5 \mathrm{~h}$ leads to structure distortion and decrease of $\mathrm{Eu}^{3+}$ local symmetry environment.

In Figure 10, the room-temperature luminescence decay curves of ${ }^{5} \mathrm{D}_{0} \longrightarrow{ }^{7} \mathrm{~F}_{2}$ transition of $\mathrm{Eu}^{3+}$ are shown for the samples annealed at 300,600 , and $900^{\circ} \mathrm{C}$ for $1 \mathrm{~h}$ (Figures $10(\mathrm{a})-10(\mathrm{c})$ ) and at $900^{\circ} \mathrm{C}$ for $4 \mathrm{~h}$ (Figure $10(\mathrm{~d})$ ). The excitation wavelength is fixed at $275 \mathrm{~nm}$. The common factors affecting the decay kinetics behavior are the number of different luminescent centers, defects, energy transfer, and impurities in the host [62]. The raw data recorded for the 


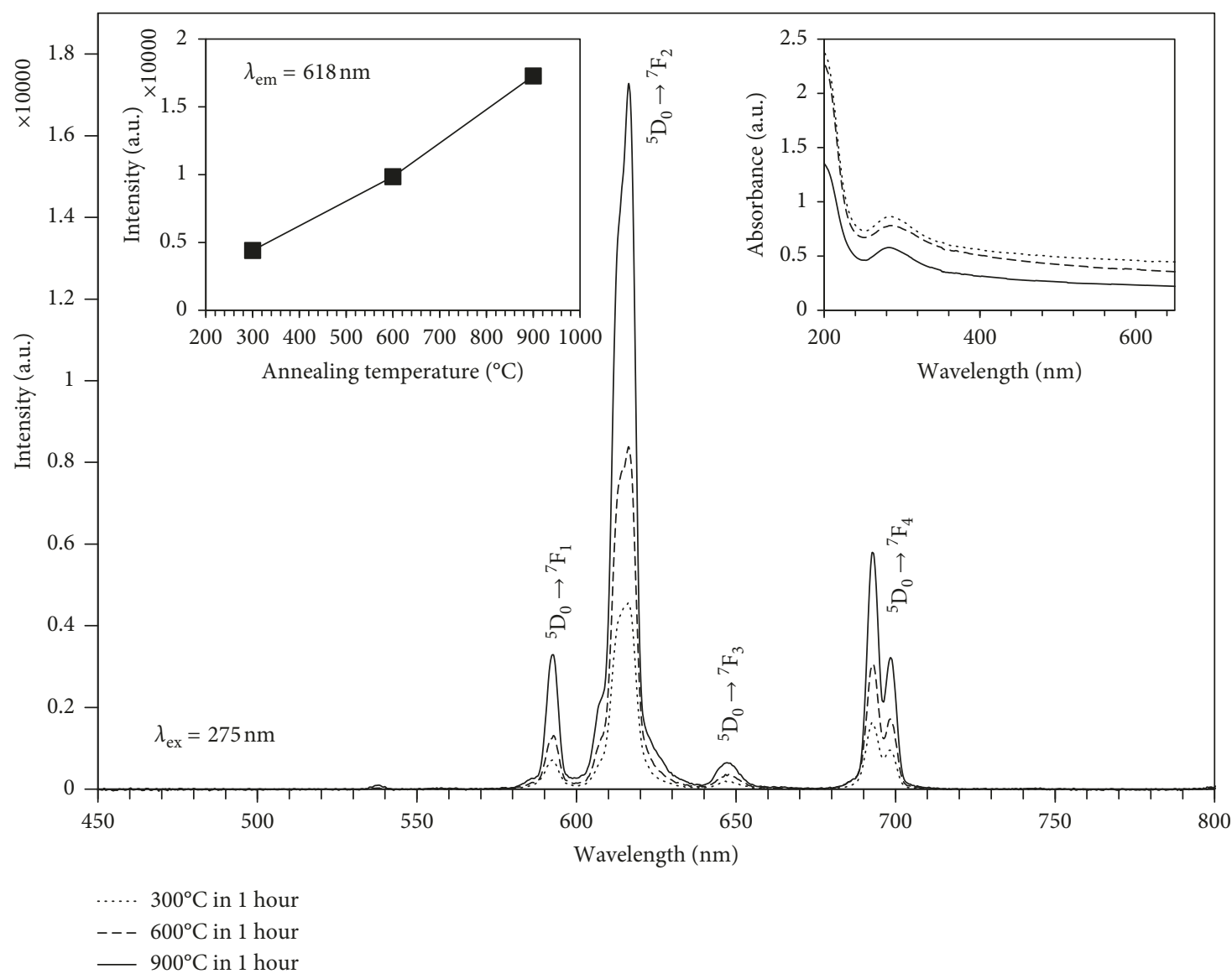

FIGURE 8: Photoluminescence spectra of samples at different annealed temperatures. Inset (right) shows the $\mathrm{UV}^{-\mathrm{V}}$ is $\mathrm{spectra} \mathrm{ff} \mathrm{YVO}_{4}: \mathrm{Eu}^{3+}$ nanoparticles with different annealed temperatures; left inset is the diagram of dependence of ${ }^{5} \mathrm{D}_{0}-{ }^{7} \mathrm{~F}_{2}$ intensity on annealing temperature.

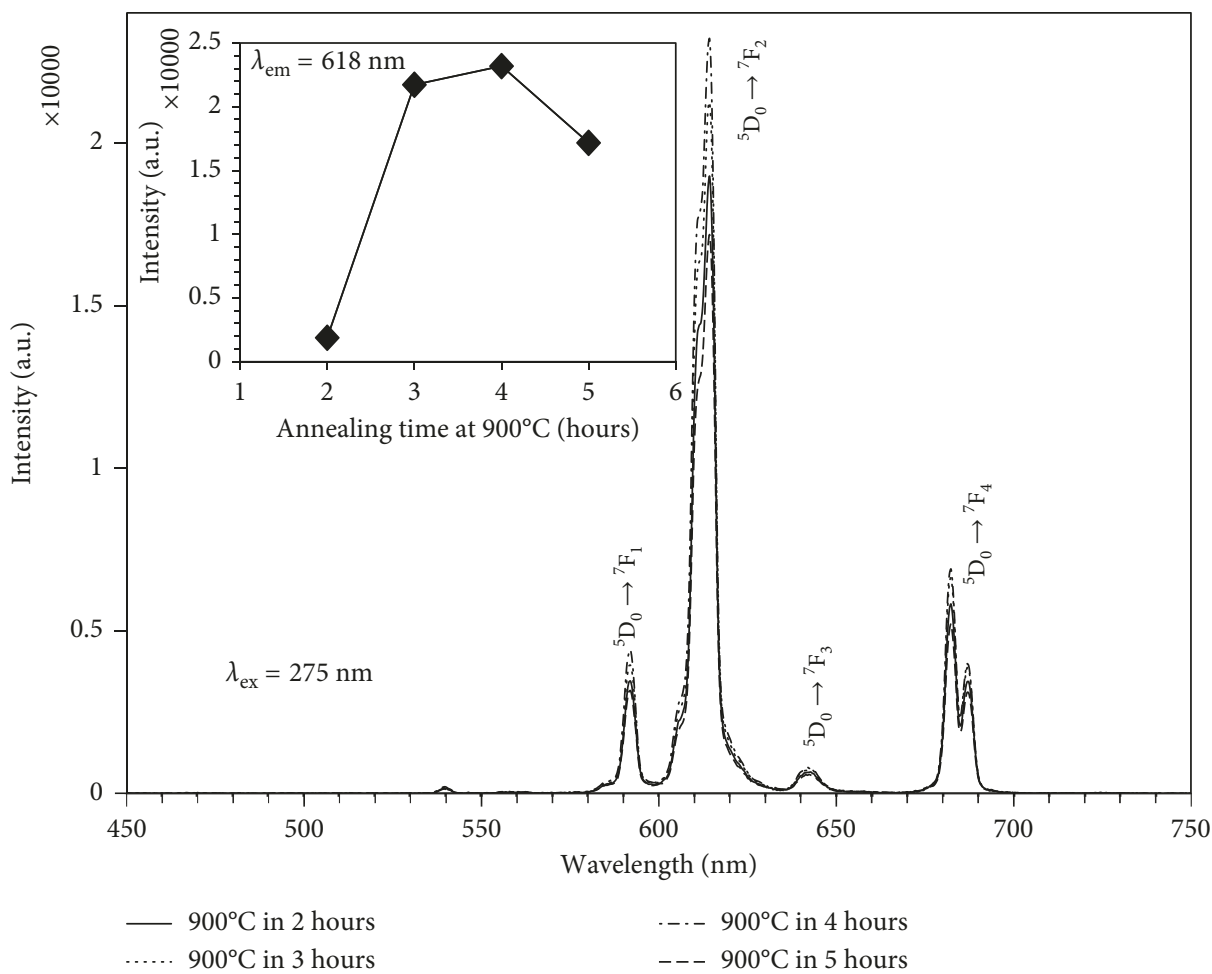

Figure 9: Photoluminescence spectra of samples annealed at $900^{\circ} \mathrm{C}$ in different durations. Inset shows diagram of dependence of ${ }^{5} \mathrm{D}_{0}{ }^{-} \mathrm{F}_{2}$ intensity on the annealing time at $900^{\circ} \mathrm{C}$. 
TABLe $1:{ }^{5} \mathrm{D}_{0} \longrightarrow{ }^{7} \mathrm{~F}_{2} /{ }^{5} \mathrm{D}_{0} \longrightarrow{ }^{7} \mathrm{~F}_{1}$ relative emission intensity ratio.

\begin{tabular}{lc}
\hline Sample & ${ }^{5} \mathrm{D}_{0} \longrightarrow{ }^{7} \mathrm{~F}_{2} /{ }^{5} \mathrm{D}_{0} \longrightarrow{ }^{\circ} \mathrm{F}_{1}$ \\
\hline $300^{\circ} \mathrm{C}-1 \mathrm{~h}$ & 8.80 \\
$600^{\circ} \mathrm{C}-1 \mathrm{~h}$ & 5.58 \\
$900^{\circ} \mathrm{C}-1 \mathrm{~h}$ & 5.26 \\
$900^{\circ} \mathrm{C}-2 \mathrm{~h}$ & 6.38 \\
$900^{\circ} \mathrm{C}-3 \mathrm{~h}$ & 5.97 \\
$900^{\circ} \mathrm{C}-4 \mathrm{~h}$ & 5.71 \\
$900^{\circ} \mathrm{C}-5 \mathrm{~h}$ & 5.87 \\
\hline
\end{tabular}

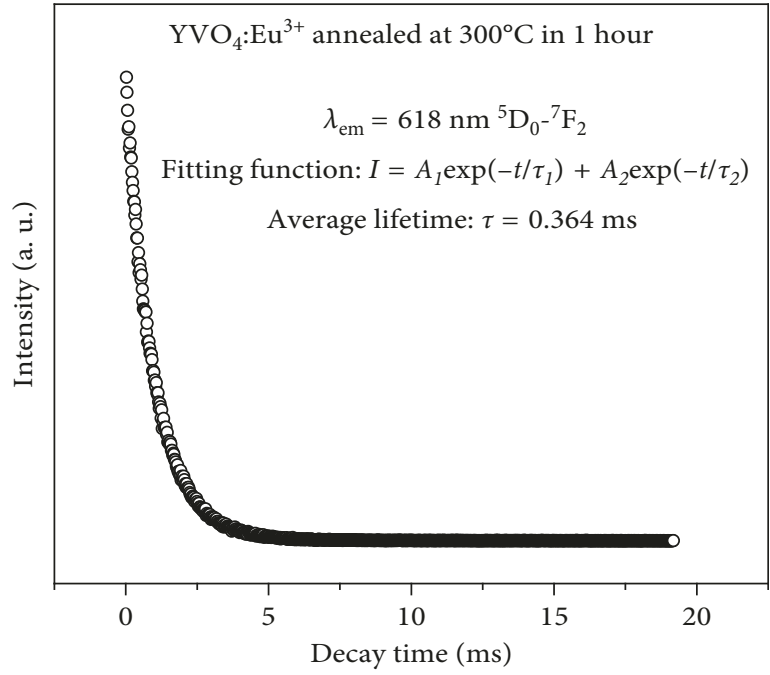

(a)

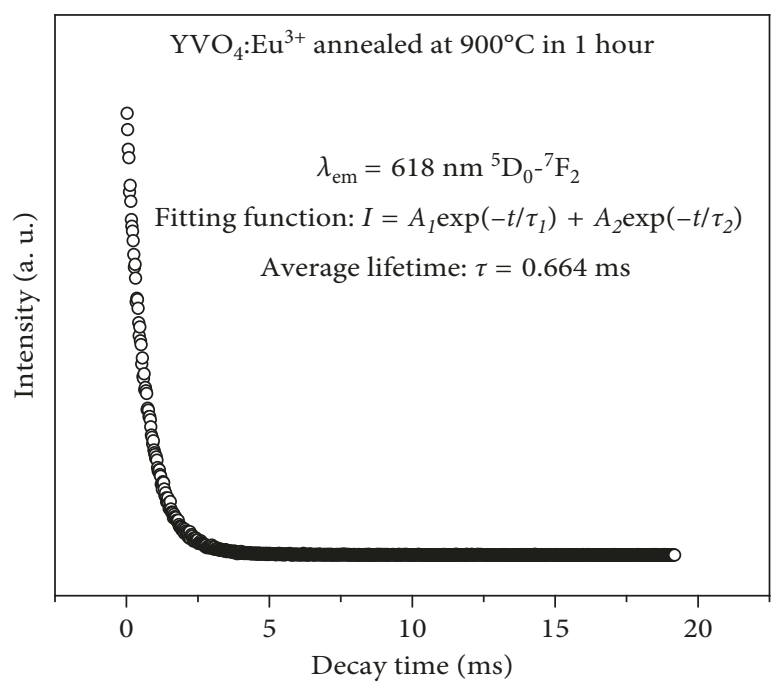

(c)

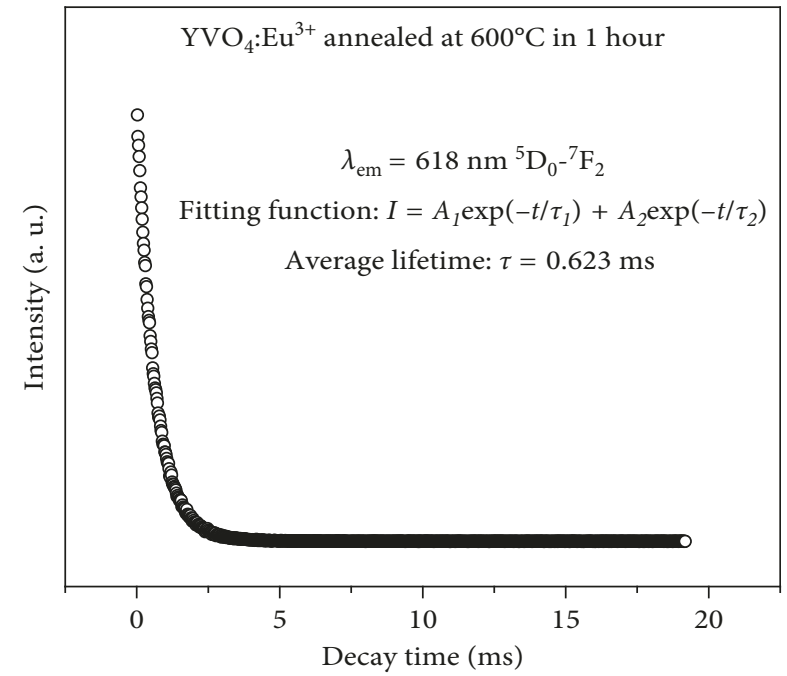

(b)

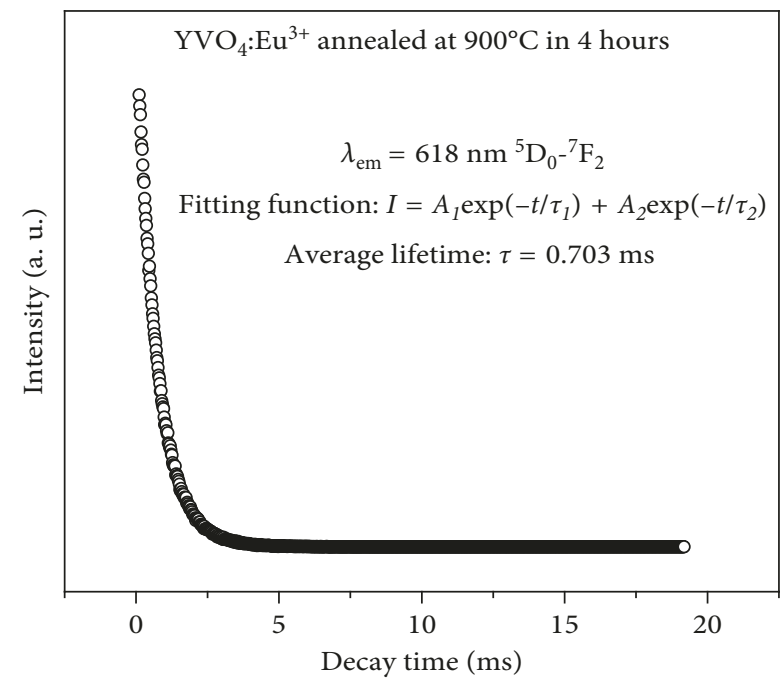

(d)

Figure 10: The luminescence decay curves for the ${ }^{5} \mathrm{D}_{0}$ excited state of $\mathrm{Eu}^{3+}$ under $275 \mathrm{~nm}$ excitation for $\mathrm{YVO}_{4}$ :Eu ${ }^{3+}$ samples synthesized with different annealing temperatures and durations.

decay curves of all samples are well-fitted by a double-exponential function (equation (2)).

$$
I=A_{1} \exp \left(\frac{-t}{\tau_{1}}\right)+A_{2} \exp \left(\frac{-t}{\tau_{2}}\right)
$$

where $I$ is the luminescence intensity at time $t, A$ is the fitting parameter, and $\tau$ is the decay lifetime, respectively. The average lifetimes of the $\mathrm{Eu}^{3+}$ ions in samples annealed at 300 , 600 , and $900^{\circ} \mathrm{C}$ in $1 \mathrm{~h}$ at $618 \mathrm{~nm}$ emission under $275 \mathrm{~nm}$ excitation are calculated to be $0.364,0.623$, and $0.644 \mathrm{~ms}$. The 
TABLE 2: Formulation of $\mathrm{YVO}_{4}: \mathrm{Eu}^{3+}$ nanoparticles ink.

\begin{tabular}{lccccc}
\hline Ingredient & $\mathrm{YVO}_{4}: \mathrm{Eu}^{3+}$ & Glycerin & Ethanol & Ethyl acetate & Ethylene glycol \\
\hline Percentage (\% wt.) & 8 & 62 & 16 & 4 & 10 \\
\hline
\end{tabular}
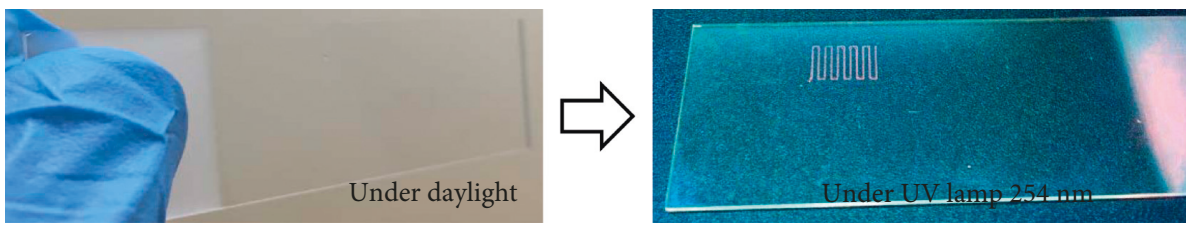

(a)
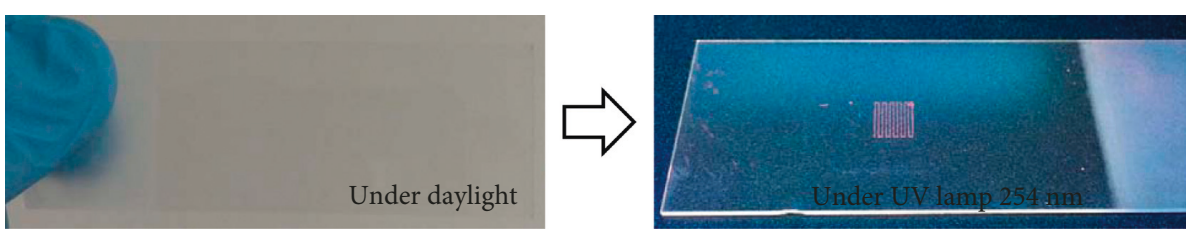

(b)

FIGURE 11: The image of lines under daylight and UV lamp, labels with distance between two lines at $300 \mu \mathrm{m}$ (a) and $800 \mu \mathrm{m}$ (b).

average lifetime increases with the increase of annealing temperature from $300^{\circ} \mathrm{C}$ to $900^{\circ} \mathrm{C}$. The decay lifetime difference may appear due to the nonradiative transition caused by the surface defects and/or crystallinity rate [42]. The higher the annealing temperature, the lower the surface effect. As shown in Figures 10(c) and 10(d) the average decay lifetime of $\mathrm{Eu}^{3+}$ ions in sample annealed at $900^{\circ} \mathrm{C}$ for $4 \mathrm{~h}$ is $0.703 \mathrm{~ms}$, which is longer than that in the sample annealed at $900^{\circ} \mathrm{C}$ for $1 \mathrm{~h}$. The measured decay time comprises both radiative and nonradiative transmission. The radiative decay component is dependent upon the number of light emitting activator ions in the nanoparticles [44]. We assume that $\mathrm{Eu}^{3+}$ ions doped in host lattice are light emitting activators, meaning that the occupancy of $\mathrm{Eu}^{3+}$ ions to $\mathrm{Y}^{3+}$ sites in the samples annealed at $900^{\circ} \mathrm{C}$ for $4 \mathrm{~h}$ is better than that in the sample treated for $1 \mathrm{~h}$.

3.3. Test Security Printing. There are very few reports on the use of rare earth ions as luminescent colloids. The typical report of Gupta et al. is the usage of spherical $\mathrm{Y}_{2} \mathrm{O}_{3}: \mathrm{Eu}^{3+}$ nanoparticles as security ink for screen printing technique, and Meruga et al. studied the security ink from the rare earth nanoparticles $\beta$ $\mathrm{NaYF}_{4}$-doped $\mathrm{Yb}^{3+} / \mathrm{Er}^{3+}$ and $\mathrm{Yb}^{3+} / \mathrm{Tm}^{3+}$ to print security QR code by Optomec direct-write aerosol jetting. Our purpose is printing label at small size, from micrometer to millimeter, with high sharpness in order to increase the security ability for product. Therefore, we use $\mathrm{YVO}_{4}: \mathrm{Eu}^{3+}$ to produce ink for the PS JET $300 \mathrm{~V}$ inkjet printer. This printer is operated by the electrohydrodynamic (EHD) inkjet technique. The advantage of the EHD inkjet technique is the ability to print labels at small size (in micrometer) on various material substrates.

For the preparation of security ink, the $\mathrm{YVO}_{4}: \mathrm{Eu}^{3+}$ nanoparticles are synthesized by the sonochemical method and then redissolved into organic solvents. On the basis of the above results, $\mathrm{YVO}_{4}: \mathrm{Eu}^{3+}$ nanoparticles, synthesized by the sonochemical method and annealed at $900^{\circ} \mathrm{C}$ for $4 \mathrm{~h}$, are most appropriate to be used as security ink in inkjet printing due to

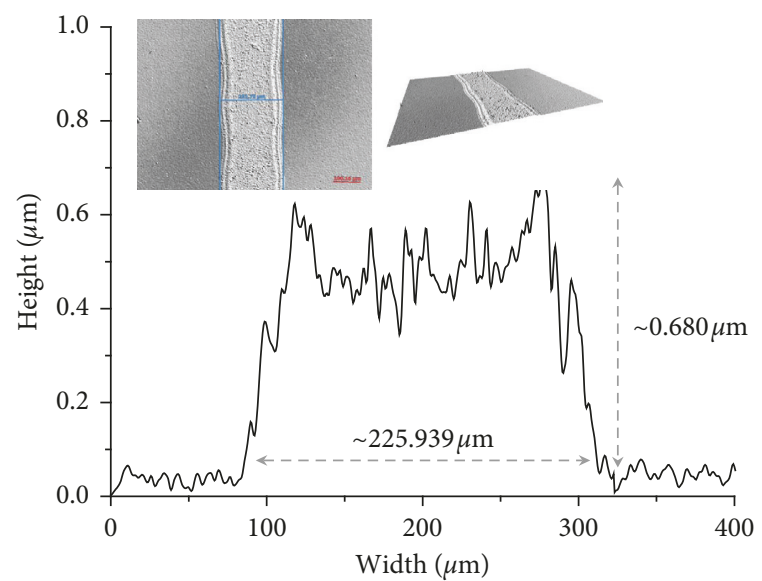

FIgURE 12: The height-width diagram of section of line after printed. Inset shows the micrograph of the respective line taken by Sensofar Metrology 3D microscope technique.

high luminescent intensity at $618 \mathrm{~nm}$ and proper size for not clogging the printhead. Formulation of $\mathrm{YVO}_{4}: \mathrm{Eu}^{3+}$ nanoparticles ink is shown in Table 2 with the viscosity at $\sim 350 \mathrm{cP}$. The printhead is made of metal with diameter at $\sim 198 \mu \mathrm{m}, \mathrm{DC}$ voltage at $1500 \mathrm{~V}$, frequency at $500 \mathrm{~Hz}$, distance between print head and substrate at around $150 \mu \mathrm{m}$, and printing speed at $20 \mathrm{~mm} / \mathrm{s}$. We perform printing experiment with representative line security labels at small size length of $5 \mathrm{~mm}$ and distance between two lines set at 300 and $800 \mu \mathrm{m}$.

The printed line image on glass substrate under daylight and UV lamp $254 \mathrm{~nm}$ is shown in Figure 11. The lines printed in Figure 11(a) are with distance set at $800 \mu \mathrm{m}$ apart and length at $5 \mathrm{~mm}$ and Figure 11(b) with length at $5 \mathrm{~mm}$ and distance set at $300 \mu \mathrm{m}$ apart. In this experiment, the printed lines are nearly transparent under daylight and have red color luminescence under UV lamp working at $254 \mathrm{~nm}$. The lines are clear, sharp, seamless, and not overlapped over each other even at small distance, $300 \mu \mathrm{m}$. 
The sample with distance of $800 \mu \mathrm{m}$ between two lines set is analyzed by Sensofar Metrology 3D microscope technique. Figure 12 and inset present the height-width diagram of section of line after being printed and the micrograph of the respective line. The line is seamless with the width at $\sim 230 \mu \mathrm{m}$ and thickness at $\sim 0.68 \mu \mathrm{m}$. According to this result, there is a possibility of printing small security labels with micrometer to millimeter size on glass substrate in order to enhance security property.

\section{Conclusion}

The $\mathrm{YVO}_{4}: \mathrm{Eu}^{3+}$ nanoparticles are synthesized by thermal stirring and microwave and sonochemical methods. According to the analyzed result, the crystallization of $\mathrm{YVO}_{4}: \mathrm{Eu}^{3+}$ nanoparticles appears in the tetragonal structure and the phosphor has the strongest luminescence at wavelength of $618 \mathrm{~nm}$ due to ${ }^{5} \mathrm{D}_{0} \longrightarrow{ }^{7} \mathrm{~F}_{2}$ transition. The creation of the high local temperature and pressure by the sonochemical method has positive effect on the formation of crystalline $\mathrm{YVO}_{4}: \mathrm{Eu}^{3+}$ nanoparticles and doping of $\mathrm{Eu}^{3+}$ ions into $\mathrm{Y}^{3+}$ position. As shown by TEM observation, the average size of $\mathrm{YVO}_{4}: \mathrm{Eu}^{3+}$ nanoparticles synthesized by the sonochemical method is $\sim 23 \mathrm{~nm}$.

The value of $\mathrm{pH}$ in the synthesized solution has influence on the emission intensity of $\mathrm{YVO}_{4}: \mathrm{Eu}^{3+}$ nanoparticles, as $\mathrm{pH}$ at 12 is the most appropriate value. Concerning annealing at different temperatures, $\mathrm{YVO}_{4}: \mathrm{Eu}^{3+}$ nanoparticles show the strongest luminescence intensity when being annealed at $900^{\circ} \mathrm{C}$. The optimal luminescence intensity appears in the sample annealed at $900^{\circ} \mathrm{C}$ for $4 \mathrm{~h}$. The size of $\mathrm{YVO}_{4}: \mathrm{Eu}^{3+}$ nanoparticles is proportional to the annealing temperature, and the average size of $\mathrm{YVO}_{4}: \mathrm{Eu}^{3+}$ nanoparticles is $\sim 170 \mathrm{~nm}$ at $900^{\circ} \mathrm{C}$ applied for $1 \mathrm{~h}$. The average lifetimes of the $\mathrm{Eu}^{3+}$ ions emission at $618 \mathrm{~nm}$ under $275 \mathrm{~nm}$ excitation of the samples annealed at 300,600 , and $900^{\circ} \mathrm{C}$ for $1 \mathrm{~h}$ are 0.364 , 0.623 , and $0.644 \mathrm{~ms}$, whereas the value in the sample annealed at $900^{\circ} \mathrm{C}$ for $4 \mathrm{~h}$ is $0.703 \mathrm{~ms}$.

Analysis of the results shows that the lines printed by inkjet technique is solid and even with the width at $\sim 230 \mu \mathrm{m}$, the thickness at $\sim 0.68 \mu \mathrm{m}$, and the smallest distance of two adjacent lines at $300 \mu \mathrm{m}$. The test lines are nearly invisible under daylight, and they are red under UV mercury lamps with wavelength of $\sim 254 \mathrm{~nm}$.

\section{Data Availability}

No data were used to support this study.

\section{Conflicts of Interest}

The authors declare that they have no conflicts of interest.

\section{Acknowledgments}

The authors would like to give the appreciation to the Vietnam National University, Ho Chi Minh City (VNUHCM), no. C2017-32-01/HĐ-KHCN.

\section{References}

[1] T. Jüstel, H. Nikol, and C. Ronda, "New developments in the field of luminescent materials for lighting and displays," Angewandte Chemie International Edition, vol. 37, no. 22, pp. 3084-3103, 1998.

[2] V. L. Colvin, M. C. Schlamp, and A. P. Alivisatos, "Lightemitting diodes made from cadmium selenide nanocrystals and a semiconducting polymer," Nature, vol. 370, no. 6488, pp. 354-357, 1994.

[3] B. O. Dabbousi, M. G. Bawendi, O. Onitsuka, and M. F. Rubner, "Electroluminescence from CdSe quantumdot/polymer composites," Applied Physics Letters, vol. 66, no. 11, pp. 1316-1318, 1995.

[4] V. I. Klimov, A. A. Mikhailovsky, S. Xu et al., "Optical gain and stimulated emission in nanocrystal quantum dots," Science, vol. 290, no. 5490, pp. 314-317, 2000.

[5] M. P. Bruchez, M. Moronne, P. Gin, S. Weiss, and A. P. Alivisatos, "Semiconductor nanocrystals as fluorescent biological labels," Science, vol. 281, no. 5385, pp. 2013-2016, 1998.

[6] Z. Xia, Y. Zhang, M. S. Molokeev, and V. V. Atuchin, "Structural and luminescence properties of yellow-emitting $\mathrm{NaScSi}_{2} \mathrm{O}_{6}: \mathrm{Eu}^{2+}$ phosphors: $\mathrm{Eu}^{2+}$ site preference analysis and generation of red emission by codoping $\mathrm{Mn}^{2+}$ for white-lightemitting diode applications," Journal of Physical Chemistry $C$, vol. 117, no. 40, pp. 20847-20854, 2013.

[7] C. Shen and Y. Yang, "Synthesis and luminous characteristics of $\mathrm{Ba}_{2} \mathrm{MgSiO}_{5}: \mathrm{Eu}^{2+}$ Phosphor," Materials and Manufacturing Processes, vol. 26, no. 10, pp. 1335-1337, 2011.

[8] J. Chandradass and K. H. Kim, "Reverse micelle-directed syn-

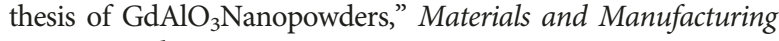
Processes, vol. 25, no. 12, pp. 1428-1431, 2010.

[9] S. K. Sahoo, M. Mohapatra, A. K. Singh, and S. Anand, "Hydrothermal synthesis of single crystalline nano $\mathrm{CeO}_{2}$ and its structural, optical, and electronic characterization," $M a$ terials and Manufacturing Processes, vol. 25, no. 9, pp. 982989, 2010

[10] B. Dong, D. P. Liu, X. J. Wang, T. Yang, S. M. Miao, and C. R. Li, "Optical thermometry through infrared excited green upconversion emissions in $\mathrm{Er}^{3+}-\mathrm{Yb}^{3+}$ codoped $\mathrm{Al}_{2} \mathrm{O}_{3}$," Applied Physics Letters, vol. 90, no. 18, article 181117, 2007.

[11] R.-S. Liu, Y.-H. Liu, N. C. Bagkar, and S.-F. Hu, "Enhanced luminescence of $\mathrm{SrSi}_{2} \mathrm{O}_{2} \mathrm{~N}_{2}: \mathrm{Eu}^{2+}$ phosphors by codoping with $\mathrm{Ce}^{3+}, \mathrm{Mn}^{2+}$, and $\mathrm{Dy}^{3+}$ ions," Applied Physics Letters, vol. 91, no. 6, article 061119, 2007.

[12] C.-J. Jia, L.-D. Sun, F. Luo, X.-C. Jiang, L.-H. Wei, and C.-H. Yan, "Structural transformation induced improved luminescent properties for $\mathrm{LaVO}_{4}:$ Eu nanocrystals," Applied Physics Letters, vol. 84, no. 26, pp. 5305-5307, 2004.

[13] F. C. Palilla and A. K. Levine, "YVO ${ }_{4}$ :Eu: a highly efficient, red-emitting phosphor for high pressure mercury lamps," Applied Optics, vol. 5, no. 9, pp. 1467-1468, 1966.

[14] L. W. Wanmaker, A. Bril, W. J. Vrugt, and J. Broos, "Luminescent properties of Eu-activated phosphors of the type $\mathrm{A}^{\mathrm{III}} \mathrm{B}^{\mathrm{V}} \mathrm{O}_{4}$," Philips Research Reports, vol. 21, pp. 270-273, 1966.

[15] K. Riwotzki and M. Haase, "Wet-chemical synthesis of doped colloidal nanoparticles: $\mathrm{YVO}_{4}: \mathrm{Ln}(\mathrm{Ln}=\mathrm{Eu}, \mathrm{Sm}, \mathrm{Dy})$," Journal of Physical Chemistry B, vol. 102, no. 50, pp. 10129-10135, 1998.

[16] M. Darbandi, W. Hoheisel, and T. Nann, "Silica coated, water dispersible and photoluminescent $\mathrm{Y}(\mathrm{V}, \mathrm{P}) \mathrm{O}_{4}: \mathrm{Eu}^{3+}, \mathrm{Bi}^{3+}$ 
nanophosphors," Nanotechnology, vol. 17, no. 16, pp. 41684173, 2006.

[17] J. Kang, X.-Y. Zhang, L.-D. Sun, and X.-X. Zhang, "Bioconjugation of functionalized fluorescent $\mathrm{YVO}_{4}: \mathrm{Eu}$ nanocrystals with BSA for immunoassay," Talanta, vol. 71, no. 3, pp. 1186-1191, 2007.

[18] G. Blasse and C. B. Grabmaier, Luminescent Materials, Springer-Verlag, Berlin, Germany, 1994.

[19] W. Park, M. Jung, and D. Yoon, "Influence of $\mathrm{Eu}^{3+}, \mathrm{Bi}^{3+} \mathrm{co}-$ doping content on photoluminescence of $\mathrm{YVO}_{4}$ red phosphors induced by ultraviolet excitation," Sensors and Actuators B: Chemical, vol. 126, no. 1, pp. 324-327, 2007.

[20] F. M. Nirwan, T. K. Gundu Rao, P. K. Gupta, and R. B. Pode, "Studies of defects in $\mathrm{YVO}_{4}: \mathrm{Pb}^{2+}, \mathrm{Eu}^{3+}$ red phosphor material," Physica Status Solidi (a), vol. 198, no. 2, pp. 447-456, 2003.

[21] W. J. Park, M. K. Jung, T. Masaki, S. J. Im, and D. H. Yoon, "Characterization of $\mathrm{YVO}_{4}: \mathrm{Eu}^{3+}, \mathrm{Sm}^{3+}$ red phosphor quick synthesized by microwave rapid heating method," Materials Science and Engineering: B, vol. 146, no. 1-3, pp. 95-98, 2008.

[22] Y. Liu, H. Xiong, N. Zhang, Z. Leng, R. Li, and S. Gan, "Microwave synthesis and luminescent properties of $\mathrm{YVO}_{4}$ : $\mathrm{Ln}^{3+}(\mathrm{Ln}=\mathrm{Eu}, \mathrm{Dy}$ and $\mathrm{Sm})$ phosphors with different morphologies," Journal of Alloys and Compounds, vol. 653, no. 25, pp. 126-134, 2015.

[23] D. Natacha, A. Chrystel, P. Franck et al., "New synthesis strategies for luminescent $\mathrm{YVO}_{4}$ :Eu and $\mathrm{EuVO}_{4}$ nanoparticles with $\mathrm{H}_{2} \mathrm{O}_{2}$ selective sensing properties," Chemistry of Materials, vol. 27, no. 15, pp. 5198-5205, 2015.

[24] X. Wu, Y. Tao, C. Song, C. Mao, L. Dong, and J. Zhu, "Morphological control and luminescent properties of $\mathrm{YVO}_{4}$ : Eu nanocrystals," Journal of Physical Chemistry B, vol. 110, no. 32, pp. 15791-15796, 2006.

[25] Y.-S. Cho and Y.-D. Huh, "Photoluminescence properties of $\mathrm{YVO}_{4}$ :Eu nanophosphors prepared by the hydrothermal reaction," Bulletin of the Korean Chemical Society, vol. 31, no. 8, pp. 2368-2370, 2010.

[26] J. F. Dijksman, P. C. Duineveld, M. J. J. Hack et al., "Precision ink jet printing of polymer light emitting displays," Journal of Materials Chemistry, vol. 17, no. 6, pp. 511-522, 2007.

[27] B.-J. de Gans, S. Hoeppener, and U. S. Schubert, "Polymerrelief microstructures by inkjet etching," Advanced Materials, vol. 18, no. 7, pp. 910-914, 2006.

[28] S. M. Bidoki, D. M. Lewis, M. Clark, A. Vakorov, P. A. Millner, and D. McGorman, "Ink-jet fabrication of electronic components," Journal of Micromechanics and Microengineering, vol. 17, no. 5, pp. 967-974, 2007.

[29] S. B. Fuller, E. J. Wilhelm, and J. M. Jacobson, "Ink-jet printed nanoparticle microelectromechanical systems," Journal of Microelectromechanical Systems, vol. 11, no. 1, pp. 54-60, 2002.

[30] K. J. Lee, B. H. Jun, T. H. Kim, and J. Joung, "Direct synthesis and inkjetting of silver nanocrystals toward printed electronics," Nanotechnology, vol. 17, no. 9, pp. 2424-2428, 2002.

[31] B. K. Park, D. Kim, S. Jeong, J. Moon, and J. S. Kim, "Direct writing of copper conductive patterns by ink-jet printing," Thin Solid Films, vol. 515, no. 19, pp. 7706-7711, 2007.

[32] B. T. Nguyen, J. E. Gautrot, M. T. Nguyen, and X. X. Zhu, "Nitrocellulose-stabilized silver nanoparticles as low conversion temperature precursors useful for inkjet printed electronics," Journal of Materials Chemistry, vol. 17, no. 17, pp. 1725-1730, 2007.

[33] A. Apilux, Y. Ukita, M. Chikae, O. Chailapakul, and Y. Takamura, "Development of automated paper-based devices for sequential multistep sandwich enzyme-linked immunosorbent assays using inkjet printing," Lab Chip, vol. 13, no. 1, pp. 126-135, 2013.

[34] C. M. Dang, C. D. Trinh, D. M. T. Dang, and E. F. Blanc, "Characteristics of colloidal copper particles prepared by using polyvinyl pyrrolidone and polyethylene glycol in chemical reduction method," International Journal of Nanotechnology, vol. 10, no. 3-4, pp. 296-303, 2013.

[35] M. C. Dang, T. M. Dung Dang, and E. Fribourg-Blanc, "Inkjet printing technology and conductive inks synthesis for microfabrication techniques," Advances in Natural Sciences: Nanoscience and Nanotechnology, vol. 4, no. 1, pp. 015009015016, 2013.

[36] J. M. Meruga, W. M. Cross, P. S. May, Q. Luu, G. A. Crawford, and J. J. Kellar, "Security printing of covert quick response codes using upconverting nanoparticle inks," Nanotechnology, vol. 23, no. 39, pp. 395201-395210, 2012.

[37] B. K. Gupta, D. Haranath, S. Saini, V. N. Singh, and V. Shanker, "Synthesis and characterization of ultra-fine $\mathrm{Y}_{2} \mathrm{O}_{3}: \mathrm{Eu}^{3+}$ nanophosphors for luminescent security ink applications," Nanotechnology, vol. 21, no. 5, pp. 055607055615, 2010.

[38] S. Georgescu, E. Cotoi, A. M. Voiculescu, and O. Toma, "Effects of particle size on the luminescence of $\mathrm{YVO}_{4}: \mathrm{Eu}$ nanocrystals," Romanian Reports in Physics, vol. 60, no. 4, pp. 947-955, 2008.

[39] V. Buissette, D. Giaume, T. Gacoin, and J.-P. Boilot, "Aqueous routes to lanthanide-doped oxide nanophosphors," Journal of Materials Chemistry, vol. 16, no. 6, pp. 529-539, 2006.

[40] H. Yu, Y. Li, Y. Song et al., "Ultralong well-aligned $\mathrm{TiO}_{2}: \mathrm{Ln}^{3+}$ ( $\mathrm{Ln}=\mathrm{Eu}, \mathrm{Sm}$, or Er) fibres prepared by modified electrospinning and their temperature-dependent luminescence," Scientific Reports, vol. 7, no. 1, pp. 44099-44106, 2017.

[41] H. Wang, O. Odawara, and H. Wada, "Facile and chemically pure preparation of $\mathrm{YVO}_{4}: \mathrm{Eu}^{3+}$ colloid with novel nanostructure via laser ablation in water," Scientific Reports, vol. 6, no. 1, pp. 20507-20515, 2016.

[42] B. Shao, Q. Zhao, N. Guo et al., "Monodisperse $\mathrm{YVO}_{4}: \mathrm{Eu}^{3+}$ submicrocrystals: controlled synthesis and luminescence properties," CrystEngComm, vol. 15, no. 29, pp. 5776-5783, 2013.

[43] S. Georgescu, E. Cotoi, A. M. Voiculescu, O. Toma, and C. Matei, "Reflectance spectra of $\mathrm{YVO}_{4}: \mathrm{Eu}^{3+}$ phosphors synthesized by direct precipitation," Romanian Journal of Physics, vol. 55, no. 7, pp. 750-757, 2010.

[44] V. Kumar, A. F. Khan, and S. Chawla, "Intense red-emitting multi-rare-earth doped nanoparticles of $\mathrm{YVO}_{4}$ for spectrum conversion towards improved energy harvesting by solar cells," Journal of Physics D: Applied Physics, vol. 46, no. 36, pp. 365101-365108, 2013.

[45] F. He, P. Yang, N. Niu et al., "Hydrothermal synthesis and luminescent properties of $\mathrm{YVO}_{4}: \mathrm{Ln}^{3+}(\mathrm{Ln}=\mathrm{Eu}, \mathrm{Dy}$, and $\mathrm{Sm})$ microspheres," Journal of Colloid and Interface Science, vol. 343, no. 1, pp. 71-78, 2010.

[46] Y.-S. Cho and Y.-D. Huh, "Preparation of transparent redemitting $\mathrm{YVO}_{4}: \mathrm{Eu}$ nanophosphor suspensions," Bulletin of the Korean Chemical Society, vol. 32, no. 1, pp. 335-337, 2011.

[47] E. A. Neppiras, “Acoustic cavitation series: part one," Ultrasonics, vol. 22, no. 1, pp. 25-28, 1984.

[48] A. Henglein, "Sonochemistry: historical developments and modern aspects," Ultrasonics, vol. 25, no. 1, pp. 6-16, 1987.

[49] E. B. Flint and K. S. Suslick, "The temperature of cavitation," Science, vol. 253, no. 5026, pp. 1397-1399, 1991. 
[50] K. S. Suslick, S.-B. Choe, A. A. Cichowlas, and M. W. Grinstaff, "Sonochemical synthesis of amorphous iron," Nature, vol. 353, no. 6343, pp. 414-416, 1991.

[51] C. Bendicho, I. Lavilla, F. Pena, and M. Costas, "RSC green chemistry, chapter 4," in Challenges in Green Analytical Chemistry, vol. 13, RSC Publishing, Cambridge, UK, 2011.

[52] A. Bao, H. Lai, Y. Yang, Z. Liu, C. Tao, and H. Yang, "Luminescent properties of $\mathrm{YVO}_{4}: \mathrm{Eu} / \mathrm{SiO}_{2}$ core-shell composite particles," Journal of Nanoparticle Research, vol. 12, no. 2, pp. 635-643, 2010.

[53] L. G. Van Uitert, "Characterization of energy transfer interactions between rare earth ions," Journal of the Electrochemical Society, vol. 114, no. 10, pp. 1048-1053, 1967.

[54] C. W. Struck and W. H. Fonger, "Quantum-mechanical treatment of $\mathrm{Eu}^{+3} 4 f \longrightarrow 4 f$ and $4 f$ ? charge-transfer-state transitions in $\mathrm{Y}_{2} \mathrm{O}_{2} \mathrm{~S}$ and $\mathrm{La}_{2} \mathrm{O}_{2} \mathrm{~S}$," Journal of Chemical Physics, vol. 64, no. 4, pp. 1784-1790, 1976.

[55] J. V. Nicholas, "Origin of the luminescence in natural Zircon," Nature, vol. 215, no. 5109, p. 1476, 1967.

[56] Z. Hou, P. Yang, C. Li et al., "Preparation and luminescence properties of $\mathrm{YVO}_{4}: \mathrm{Ln}$ and $\mathrm{Y}(\mathrm{V}, \mathrm{P}) \mathrm{O}_{4}: \mathrm{Ln}\left(\mathrm{Ln}=\mathrm{Eu}^{3+}, \mathrm{Sm}^{3+}\right.$, $\left.\mathrm{Dy}^{3+}\right)$ nanofibers and microbelts by sol-gel/electrospinning process," Chemistry of Materials, vol. 20, no. 21, pp. 66866696, 2008.

[57] V. V. Atuchi, A. S. Aleksandrovsk, O. D. Chimitova et al., "Synthesis and spectroscopic properties of monoclinic $\alpha-\mathrm{Eu}_{2}\left(\mathrm{MoO}_{4}\right)_{3}$," Journal of Physical Chemistry C, vol. 118, no. 28, pp. 15404-15411, 2014.

[58] P. Shi, Z. Xia, M. S. Molokeev, and V. V. Atuchin, "Crystal chemistry and luminescence properties of red-emitting $\mathrm{CsGd}_{1-x} \mathrm{Eu}_{x}\left(\mathrm{MoO}_{4}\right)_{2}$ solid-solution phosphors," Dalton Transactions, vol. 43, no. 25, pp. 9669-9676, 2014.

[59] V. V. Atuchin, A. S. Aleksandrovsky, B. G. Bazarov et al., "Exploration of structural, vibrational and spectroscopic properties of self-activated orthorhombic double molybdate $\mathrm{RbEu}\left(\mathrm{MoO}_{4}\right)_{2}$ with isolated $\mathrm{MoO}_{4}$ units," Journal of Alloys and Compounds, vol. 785, no. 15, pp. 692-697, 2019.

[60] A. Huignard, V. Buissette, G. Laurent, T. Gacoin, and J.-P. Boilot, "Synthesis and characterizations of $\mathrm{YVO}_{4}: \mathrm{Eu}$ colloids," Chemistry of Materials, vol. 14, no. 5, pp. 2264-2269, 2002.

[61] Y. H. Li, G. F. Zang, and J. Ma, "Synthesis and luminescence properties of $\mathrm{YVO}_{4}: \mathrm{Eu}^{3+}$ nanocrystals by a sol-gel method," Advanced Materials Research, vol. 634-638, pp. 2268-2271, 2013.

[62] Y. Pu, K. Tang, D.-C. Zhu, T. Han, C. Zhao, and L.-L. Peng, "Synthesis and luminescence properties of $(\mathrm{Y}, \mathrm{Gd})(\mathrm{P}, \mathrm{V}) \mathrm{O}_{4}$ : $\mathrm{Eu}^{3+}, \mathrm{Bi}^{3+}$ red nano-phosphors with enhanced photoluminescence by $\mathrm{Bi}^{3+}, \mathrm{Gd}^{3+}$ doping," Nano-Micro Letters, vol. 5, no. 2, pp. 117-123, 2013.

[63] Z. Xu, X. Kang, C. Li et al., " $\operatorname{Ln}^{3+}(\mathrm{Ln}=\mathrm{Eu}, \mathrm{Dy}, \mathrm{Sm}$, and Er) ion-doped $\mathrm{YVO}_{4}$ nano/microcrystals with multiform morphologies: hydrothermal synthesis, growing mechanism, and luminescent properties," Inorganic Chemistry, vol. 49, no. 14, pp. 6706-6715, 2010.

[64] C. Li, Z. Hou, C. Zhang et al., "Controlled synthesis of $\mathrm{Ln}^{3+}$ $(\mathrm{Ln}=\mathrm{Tb}, \mathrm{Eu}, \mathrm{Dy})$ and $\mathrm{V}^{5+}$ ion-doped $\mathrm{YPO}_{4}$ nano-/microstructures with tunable luminescent colors," Chemistry of Materials, vol. 21, no. 19, pp. 4598-4607, 2009.

[65] R. L. Penn and J. F. Banfield, "Imperfect oriented attachment: dislocation generation in defect-free nanocrystals," Science, vol. 281, no. 5379, pp. 969-971, 1998. 

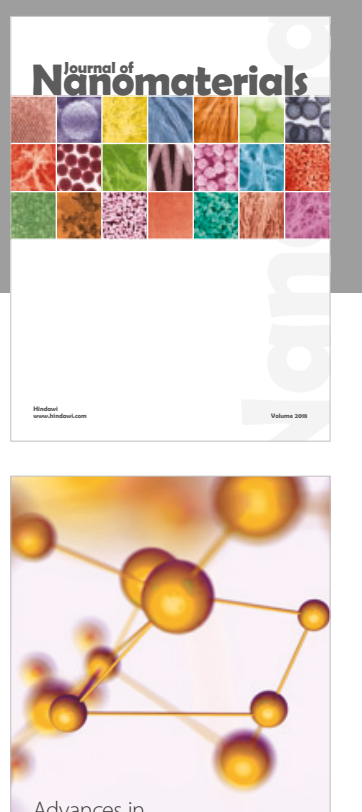

Physical Chemistry
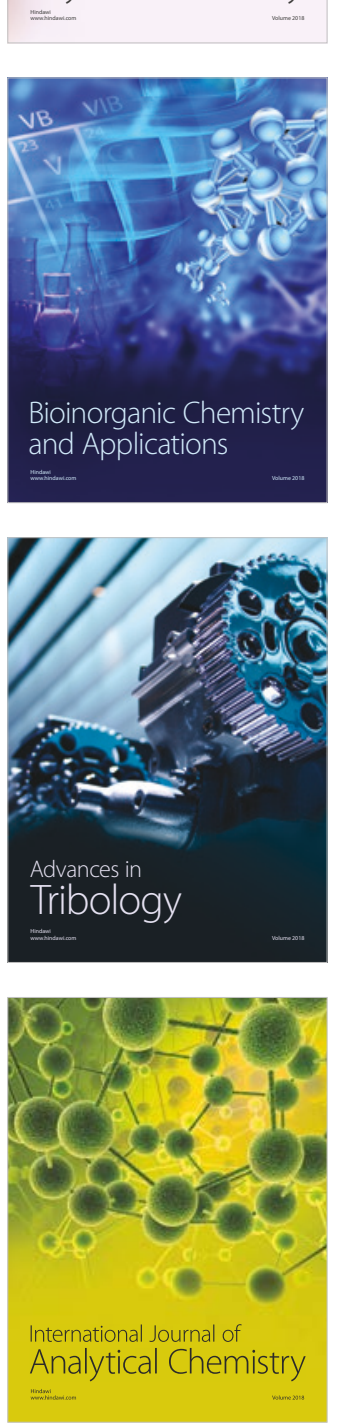

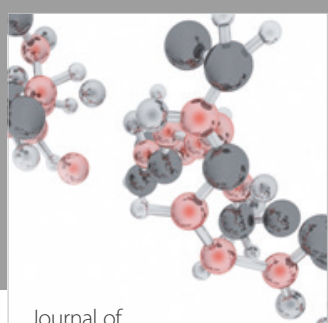

Analytical Methods

in Chemistry

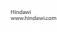

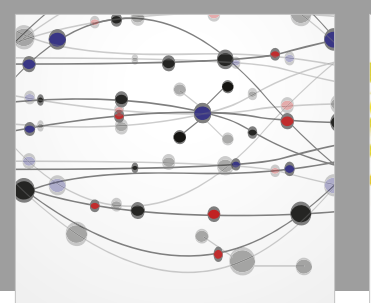

The Scientific World Journal

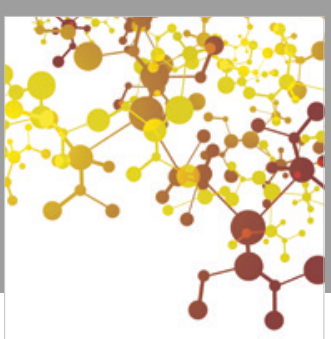

Journal of

Applied Chemistry


Submit your manuscripts at

www.hindawi.com
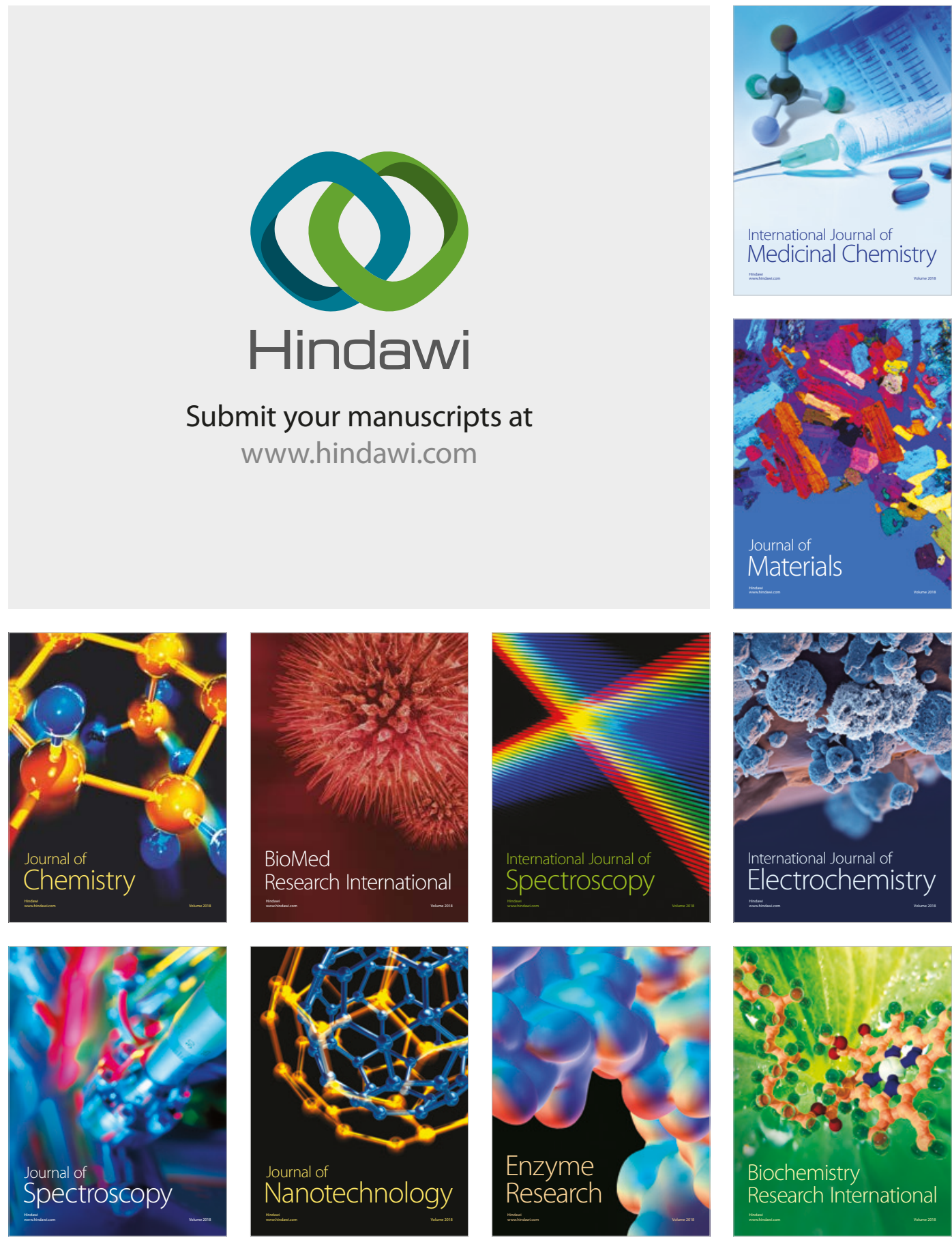
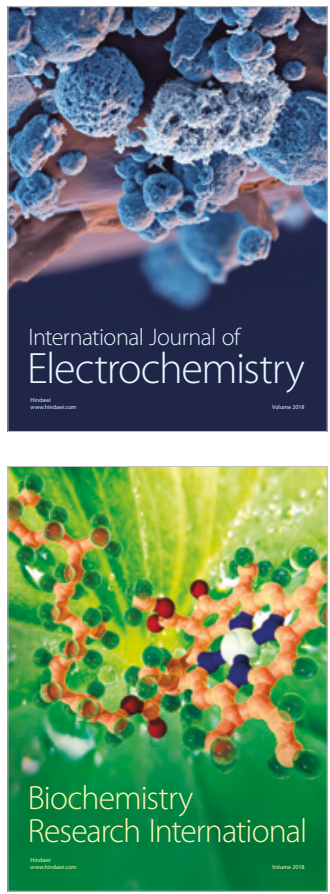